\title{
Article
}

http://dx.doi.org/10.11646/phytotaxa.208.3.1

\section{The genus Lithophyllum in the north-western Indian Ocean, with description of $L$. yemenense sp. nov., L. socotraense sp. nov., L. subplicatum comb. et stat. nov., and the resumed L. affine, L. kaiseri, and L. subreduncum (Rhodophyta, Corallinales)}

\author{
DANIELA BASSO ${ }^{1}$, ANNALISA CARAGNANO ${ }^{1,4}$, LINE LE GALL $^{2} \&$ GRAZIELLA RODONDI ${ }^{3}$ \\ ${ }^{1}$ Università degli Studi di Milano-Bicocca, Dip.to di Sc. dell'Ambiente e del Territorio e di Scienze della Terra, Sez. di Sc. Geologiche e \\ Geotecnologie, Piazza della Scienza 4, 20126 Milano, Italy. \\ ${ }^{2}$ Unité Mixte de Recherche 7205, Equipe "Exploration, Espèces et Evolution”, Institut de Systématique, Evolution, Biodiversité, ISYEB \\ - UMR 7205 - CNRS, MNHN, UPMC, EPHE, Muséum National d'Histoire Naturelle, Paris, France. \\ ${ }^{3}$ Università degli Studi di Milano, Dip.to di Bioscienze, Via Celoria 26, 20133 Milano, Italy. \\ ${ }^{4}$ Present address: Inst. pour la Recherche et le Développement (IRD), UMR ENTROPIE Centre de Nouméa, Promenade Laroque, \\ 98848 Nouméa, New Caledonia. \\ Corresponding author: daniela.basso@unimib.it, Fax+39-0264482073
}

\begin{abstract}
Based on literature, the genus Lithophyllum was represented in the whole Indian Ocean by 14 taxa, mostly in need of revision in a modern context. Molecular analyses integrated with morpho-anatomical comparisons between the recently revised type material of Lithophyllum kotschyanum Unger, and the related infraspecific taxa, lead to a resumption of $L$. affine, L. kaiseri, and L. subreduncum, and the description of L. socotraense sp. nov., L. yemenense sp. nov., and L. subplicatum comb. et stat. nov. Detailed accounts are provided for each species, including keys, along with information on synonymy, examined collections, distribution, habitat as well as sequence data of the 5' end of the LSU from the type specimens. The anatomical features of the tetrasporangial conceptacle that were considered collectively diagnostic for species identification are: the mean diameter of the tetrasporangial conceptacles, the length of the pore-canal in the tetrasporangial conceptacles (with the number of cells in roof filaments), the occurrence of a depression at the top of the conceptacle roof in relation to the pore opening, and the number of cells from the floor of the tetrasporangial conceptacle chamber to the thallus surface. This study provides evidence of a previously unsuspected diversity within the Red Sea and NW Indian Ocean species of Lithophyllum.
\end{abstract}

Key words: biodiversity, coralline algae, Foslie, Heydrich, Indo-Pacific Ocean, Red Sea, Arabian Sea, Persian Gulf, integrated taxonomy, Lithophylloideae, TRH

\section{Introduction}

The coralline flora of the Indian Ocean is insufficiently known. A survey of the literature available for the area revealed that the subfamily Lithophylloideae was represented by 19 species and infraspecific taxa, and that 8 of them were in need of a revision in a modern taxonomic context. In particular, only Lithophyllum kotschyanum Unger, and its infraspecific taxa L. kotschyanum forma affine and L. kotschyanum forma subplicatum, together with L. orbiculatum and L. okamurae, were listed from the NW Indian Ocean (including Red Sea, Gulf of Aden, Arabian Sea, and Persian Gulf, in the boreal emisphere, and toward the east to include the western Indian coasts; Table 1).

In the framework of a large-scale investigation on Red Sea and Indian Ocean corallines, we collected some common Lithophyllum plants, bearing abundant trichocytes (Basso et al. 2014). In order to correctly identify the species, we provided morphological and molecular data (the 5 'end of the nuclear LSU) to compare the recently revised type material of L. kotschyanum Unger, and the related infraspecific taxa, namely L. kotschyanum forma affine, L. kotschyanum forma madagascarense, L. kotschyanum forma subplicatum and L. kotschyanum forma subreduncum, housed at TRH (abbreviations following Holmgren continuously updated). The objective of this study is to use both morphological and molecular data to assess species delineation within this taxon. This study contributes to the discussion on coralline biodiversity in the north-western Indian Ocean and Red Sea, focusing on the genus Lithophyllum. 
TABLE 1. Lithophyllum species and infraspecific taxa from the Indian Ocean, after Silva et al. 1996; Womersley 1996; Maneveldt et al. 2008; Basso et al. 2014. An asterisk before the binomial indicates those species that should belong to the genus Titanoderma, based on Bailey (1999), and Schneider \& Wynne (2007). In the column of the Indian Ocean distribution, the type locality is italicized. Unchecked reports of the Lithophyllum species discussed here are in square brackets. Note that only L. kotschyanum, its infraspecific taxa L. kotschyanum f. affine and L. kotschyanum f. subplicatum, L. orbiculatum and L. okamurae were reported from the NW Indian Ocean before this study.

\begin{tabular}{|c|c|c|}
\hline Indian Ocean Lithophyllum species & Indian Ocean distribution & modern account \\
\hline L. acrocamptum Heydrich 1902 & $\begin{array}{l}\text { Kenya, Madagascar, Mauritius, } \\
\text { S. Africa, Sri Lanka }\end{array}$ & $\begin{array}{l}\text { Chamberlain } 1996 \text { (as } L . \\
\text { incrassatum) }\end{array}$ \\
\hline L. bamleri (Heydrich) Heydrich 1897 & Comoro Islands, Sri Lanka, Indonesia (Timor) & \\
\hline $\begin{array}{l}\text { *L. chamberlainianum Woelkerling \& Campbell } \\
1992\end{array}$ & Australia, Tasmania & Woelkerling \& Campbell 1992 \\
\hline $\begin{array}{l}\text { *L. corallinae (Crouan \& Crouan) Heydrich } \\
1897\end{array}$ & Australia, Tasmania & Woelkerling \& Campbell 1992 \\
\hline L. incrustans Philippi 1837 & Mauritius, Reunion, S. Africa & Chamberlain 1996 \\
\hline *L. irvineanum Woelkerling \& Campbell 1992 & Australia & Woelkerling \& Campbell 1992 \\
\hline L. johansenii Woelkerling \& Campbell 1992 & Australia & Woelkerling \& Campbell 1992 \\
\hline L. kotschyanum Unger 1858 & $\begin{array}{l}\text { Persian Gulf [Dijbouti, Laccadive Islands, } \\
\text { Maldives, Sri Lanka, Comoro Islands, } \\
\text { Seychelles, Madagascar, Mauritius, Reunion, } \\
\text { Rodriguez, Diego Garcia Atoll, Cocos Islands, } \\
\text { Kenya, Indonesia] }\end{array}$ & Basso et al. 2014 \\
\hline L. kotschyanum f. affine (Foslie) Foslie 1909 & Massawa, Red Sea [Seychelles] & $\begin{array}{l}\text { this paper: Lithophyllum affine } \\
\text { (Foslie) Foslie }\end{array}$ \\
\hline L. kotschyanum f. subplicatum (Foslie) Silva & [Cocos Islands, Comoro Islands, Diego & this paper: Lithophyllum \\
\hline 1996 & $\begin{array}{l}\text { Garcia Atoll, Laccadive Islands, Maldives, } \\
\text { Madagascar, Mauritius, Mozambique, Réunion, } \\
\text { Seychelles] }\end{array}$ & $\begin{array}{l}\text { subplicatum (Foslie) } \\
\text { comb. et stat. nov. }\end{array}$ \\
\hline L. okamurae Foslie 1900 & Cocos Islands, India, Indonesia (Timor, Semau) & \\
\hline L. orbiculatum (Foslie) Foslie 1900 & India & Chamberlain \& Irvine 1994 \\
\hline L. pallescens (Foslie) Foslie 1900 & Mauritius & \\
\hline L. pinguinense Heydrich 1901 & St. Paul Island & \\
\hline *L. prototypum (Foslie) Foslie 1905 & $\begin{array}{l}\text { Australia, Comoro Islands, Mauritius, } \\
\text { Seychelles }\end{array}$ & Woelkerling \& Campbell 1992 \\
\hline L. punctatum Foslie 1906 & Sri Lanka & \\
\hline *L. pustulatum (Lamouroux) Foslie 1904 & Australia, Tasmania & Woelkerling \& Campbell 1992 \\
\hline L. pygmaeum (Heydrich) Heydrich 1897 & $\begin{array}{l}\text { Kenya, Madagascar, Mauritius, Seychelles, } \\
\text { Comoro Islands, Indonesia }\end{array}$ & \\
\hline L. stictaeforme (Areschoug) Hauck 1877 & Australia & Womersley 1996 (as L. frondosum) \\
\hline
\end{tabular}

\section{Material and Methods}

Plants were collected at several localities along the Yemeni coast of the Southern Red Sea, Gulf of Aden, Arabian Sea and Persian Gulf. Corallines were air dried prior transport to the Milan facilities and the selected type material was deposited in TRH.

The type material of L. kotschyanum Unger (A20-1267; A20-1272) currently housed in TRH was examined in a modern context and revised in a previous paper (Basso et al. 2014). Additionally, other geographically relevant specimens of type material were obtained from TRH including Lithophyllum kotschyanum forma madagascarense (Heydrich) Foslie (A20-1283), L. kotschyanum forma subplicatum (Foslie) Silva (A20-1286), Lithophyllum kotschyanum forma subreduncum Foslie (A20-1290; A20-1291), Lithophyllum kotschyanum forma affine (Foslie) 
Foslie (A20-1279), and Lithophyllum kaiseri (Heydrich) Heydrich (A20-1264), (further details on TRH collections are provided by Woelkerling et al. 2005).

Air-dried specimens for scanning electron microscopy (SEM) were fractured and mounted on aluminium stubs with silver glue. The samples were gold coated and examined in a SEM Vega Tescan TS5136XM at $20 \mathrm{kV}$ at the Milano-Bicocca facilities.

For light microscopy (LM), pieces of thallus were decalcified with Tellyesniczkyi's solution (Bressan 1974) for 12-48 h, washed in distilled water, dehydrated through a graded ethanol series and embedded in methacrylate resin (Technovit 7100, Heraeus Kulzer, Wehrheim, Germany). Preparation of histological slides of serial sections follows Basso \& Rodondi (2006). Permanent slides for LM were examined and photographed with a Leica DMRB photomicroscope.

The type material of L. madagascarense is a very small fragment that would have been completely destroyed for any analysis. Therefore no investigation was performed on L. madagascarense, following the recommendations of the TRH curator.

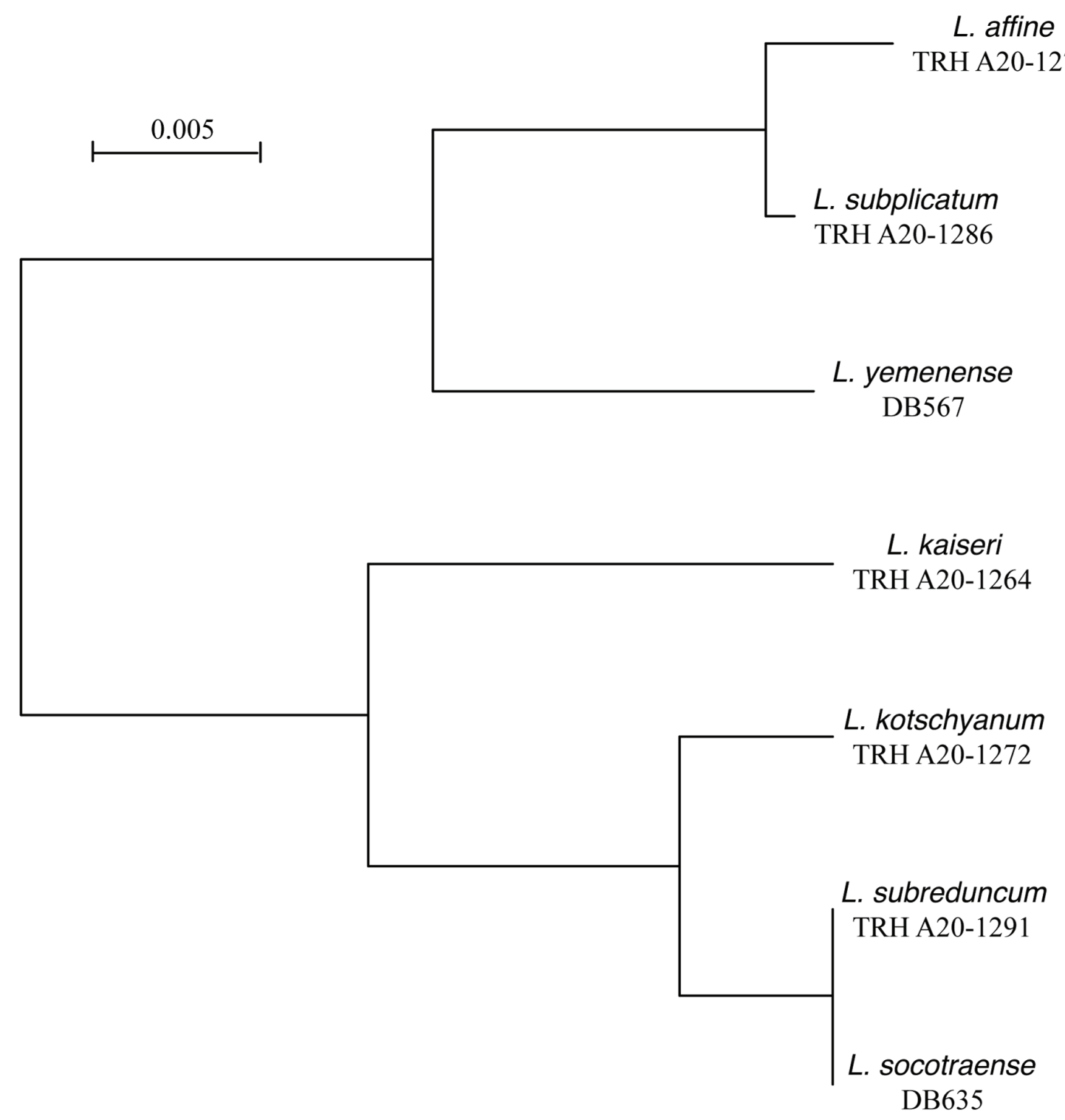

FIGURE 1. Distance analysis (Neighbor joining) performed on the 5 'end of the nuclear LSU of the seven type specimens considered in this study.

Anatomical terminology follows Adey \& Adey (1973) and Woelkerling (1988), and that for growth forms follows Woelkerling et al. (1993). Conceptacle measurements follow the system of Adey \& Adey (1973) and were made directly from the SEM or under LM using a calibrated eyepiece micrometer. Cell measurements follow Basso et al. (2004). 
For molecular analyses, specimens were sampled under the dissecting scope using a driller. Total DNA was extracted, using a DNeasy Blood \& Tissue Kit (QIAGEN, Hilden, Germany), according to the manufacturer's instructions and negative controls with no tissue were included. Two reverse primers were designed to amplify with the forward primer T01N (Harper \& Saunders 2001), small fragments of ca. 200 and 300bp of the 5' end of the nuclear LSU (28S): TR191 (5'CCACGGTACRCAWTTCCATG3') and TR273 (5'TCTCAAGCTACCCGACTC3') respectively. Purification and sequencing reactions were performed by Macrogen. Forward and reverse electropherograms were edited and assembled with the software Codoncode (Dedham, MA). Distance analysis was conducted on the LSU sequences from the type specimens to assess their divergence and Maximum likelihood analysis was conducted on a selection of taxa from GenBank and on the two recently collected type specimens to assess their phylogenetic relationship.

\section{Results}

Both reverse primers successfully amplified the 5 type specimens from TRH as well as 2 specimens of more recent collections. Distance analysis (Fig 1) revealed that divergences ranged from 0 between the pair A20-1291/ DB635 to $5.1 \%$ between A20-1279 and A20-1264, A20-1272, A20-1291 and DB635.

\section{Lithophyllum affine (Foslie) Foslie (1898: 9)}

Figures 2-3; Table 2

BASIONYM: Lithothamnion affine Foslie (1897: 13).

Nomenclatural SyNONYM: Lithothamnion affine f. complanata Foslie; Lithothamnion affine f. affine Foslie; Lithophyllum kotschyanum forma affinis (Foslie) Foslie.

Leстотуре: TRH, A20-1279 (Trondheim, Norway) (Fig. 2), (Woelkerling 1993: 21).
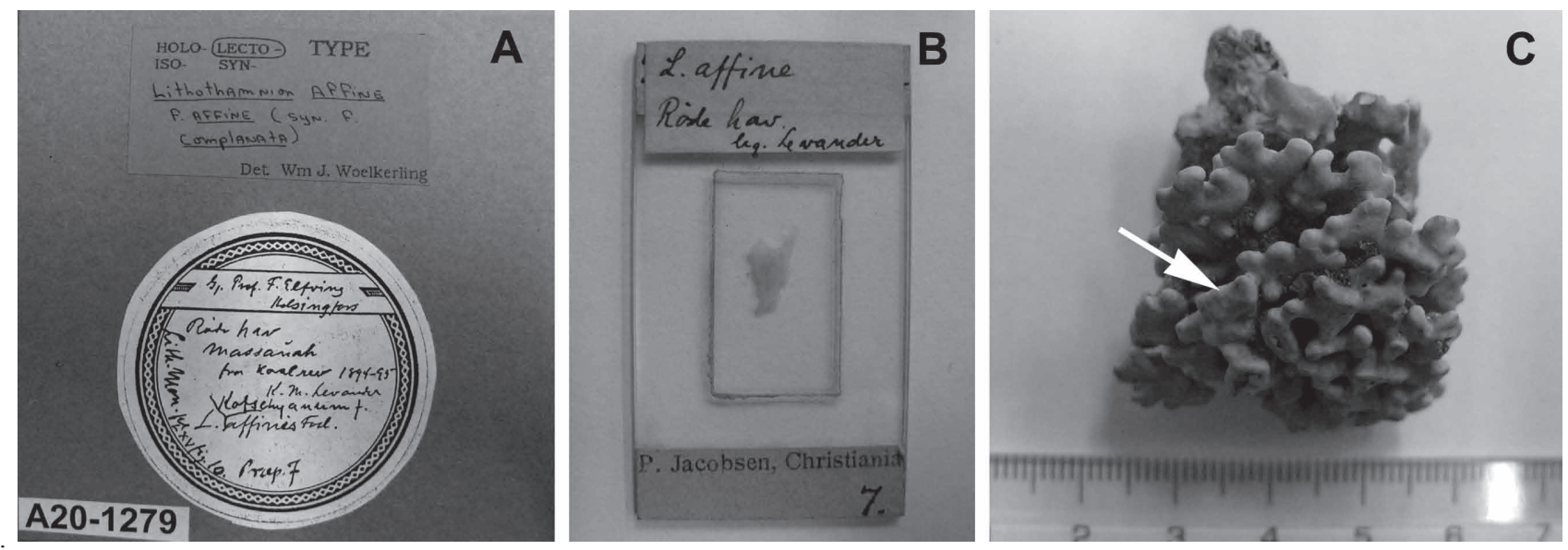

FIGURE 2. The lectotype of Lithophyllum affine (Foslie) Foslie in TRH. A) Box A20-1279 in TRH. B) Thin section 7, part of the lectotype A20-1279. C) The specimen A20-1279 in TRH, lectotype of L. affine. Note confluent and fused protuberances (arrow).

ETYMOLOGY: the specific epithet refers to the similarity (=affinity) to L. kotschyanum.

Illustrations of TYPe Material: Printz, 1929: pl. 65, fig. 10.

TYPe Locality: Massawa, Eritrea, Red Sea, collected by Levander (Woelkerling 1993; Woelkerling et al. 2005: 172-173).

Material eXAmined: Red Sea: Eritrea, Massawa, from coral reef, lectotype of $L$. affine f. affine (leg. Levander: TRH, A20-1279).

HABITAT AND PHENOLOGY: plants attached to corals, in shallow water (depth of collection unknown).

GeOGRAPHIC Distribution: Lithophyllum affine occurs in the southern Red Sea (Massawa, Eritrea). The occurrence of $L$. affine outside this area is unknown.

Habit AND VEGETATIVE StRUCtURE: The lectotype of Lithothamnion affine (TRH A20-1279) is a plant originally attached to a coral, non-endophytic, with fruticose growth-form (Fig. 2C). The protuberances have a smooth surface, are mostly compressed, branched, up to about $10 \mathrm{~mm}$ long. The branches of adjacent protuberances are fused at their tips, forming some superposed, complanate juts (Fig. 2C). Plant structure pseudoparenchymatous. Basal or ventral 
layer (= hypothallium) not observed. Peripheral region (= perithallium) composed of cell filaments curving outwards towards the thallus surface, $12-33 \mu \mathrm{m}$ long and 10-15 $\mu \mathrm{m}$ in diameter (Fig. 3A-C). Cells of adjacent filaments joined by secondary pit connections, cell fusions not observed (Fig. 3B-C). Palisade cells not observed. Single trichocytes 37-50 $\mu \mathrm{m}$ long and about $12-14 \mu \mathrm{m}$ in diameter occurring in the perithallium and at the thallus surface (Fig. 3B). Single epithallial cells flattened, about 10-13 $\mu \mathrm{m}$ in diameter and 2-3 $\mu \mathrm{m}$ long (Fig. 3C; Tab. 2).
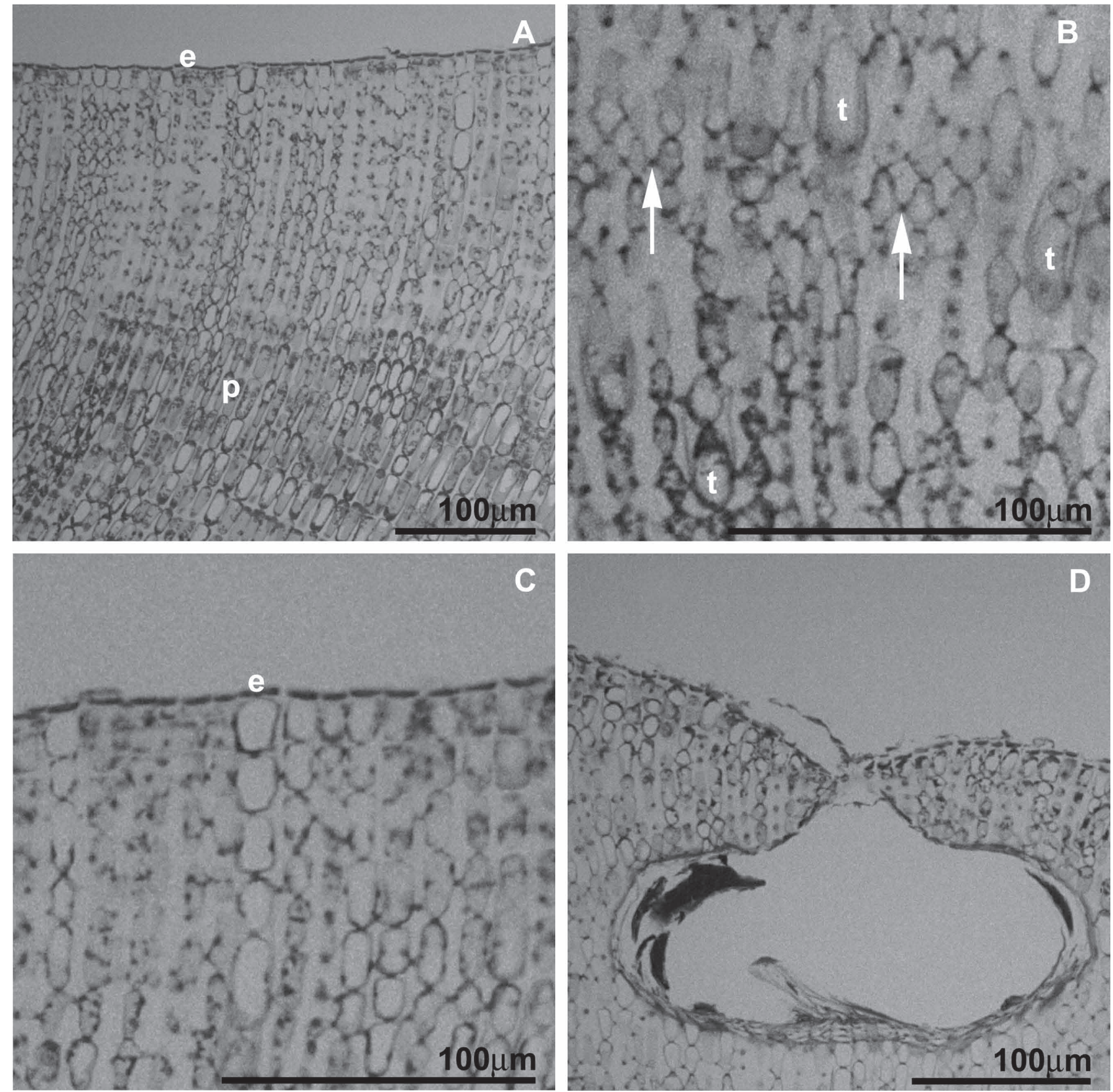

FIGURE 3. Microscopical anatomy of $L$. affine. A) Perithallial cell filaments (p) and terminal epithallial cells (e) of the lectotype of $L$. affine, slide A20-1279_12 of a decalcified fragment. B) Detail of perithallial cell filaments with secondary pit-connections (arrows) and trichocytes (t) in L. affine, slide A20-1279_12. C) Flattened epithallial cells (e), slide A20-1279_12. D) A tetrasporangial conceptacle in the lectotype A20-1279. Note the pore opening in a depression of the conceptacle chamber roof. Slide A20-1279_12.

REPRODUCTION: Uniporate tetrasporangial conceptacles slightly protruding or flush over the surrounding thallus surface, with aperture of the pore-canal in the centre of a depression. Chamber 250-280 $\mu \mathrm{m}$ in diameter and 110-130 $\mu \mathrm{m}$ high, with a pore-canal $60-70 \mu \mathrm{m}$ long. Floor of the conceptacle chamber almost flat. The conceptacle chamber floor is 11 cells below the thallus surface, including the terminal epithallial cell. Roof filaments 5-6 cells long, including the terminal epithallial cell (Fig. 3D; Tab. 2). Gametangial and carposporangial conceptacles unknown.

RePRESENTATIVE SEQUence: KP696791 (LSU). 
TABLE 2. Comparison of features and biometry of Lithophyllum kotschyanum Unger, Lithophyllum affine (Foslie) Foslie, and Lithophyllum kaiseri (Heydrich) Heydrich, from type material (TRH). Measurements in $\mu \mathrm{m}$, given as mean (standard deviation). $\mathrm{L}=\mathrm{length}$; $\mathrm{D}=$ diameter; $\mathrm{H}=$ height. Asterisk on diagnostic characters.

\begin{tabular}{|c|c|c|c|}
\hline & L. kotschyanum holotype & $\begin{array}{l}\text { L. affine } \\
\text { lectotype }\end{array}$ & $\begin{array}{l}\text { L. kaiseri } \\
\text { lectotype }\end{array}$ \\
\hline Distribution & Persian Gulf & Massawa, S Red Sea & El Tor, N Red Sea \\
\hline Life habit & $\begin{array}{l}\text { non-geniculate, habit } \\
\text { unknown }\end{array}$ & $\begin{array}{l}\text { non-geniculate, growing on } \\
\text { corals }\end{array}$ & non-geniculate, habit unknown \\
\hline Growth-form & fruticose & fruticose & fruticose \\
\hline Thallus organization & dimerous & not observed & dimerous \\
\hline *Hypothallial cells L x D & $10(2) \times 12.5(2.9)$ & not observed & $8.1(1.9) \times 11.4(3.5)$ \\
\hline Perithallium zonation & yes & yes & yes \\
\hline Perithallial cells $\mathrm{L}$ x D & $19.4(7.5) \times 8.9(1.1)$ & $22(9) \times 12.5(1.4)$ & $22.5(6.3) \times 11.6(1.9)$ \\
\hline Epithallial cells shape & flattened & flattened & flattened \\
\hline $\mathrm{L} \times \mathrm{D}$ & $2.5 \times 11(1.4)$ & $2.5 \times 11.3(1.8)$ & $2.5(0) \times 11.7(1.4)$ \\
\hline Trichocytes & yes & yes & yes \\
\hline Asexual concept. chamber & uniporate & uniporate & uniporate \\
\hline$* \mathrm{D} \times \mathrm{H}$ & $351(21.4) \times 131(18.6)$ & $265(21.2) \times 120(14.1)$ & $310(56.6) \times 105(28.3)$ \\
\hline *elevation & slightly protruding & slightly protruding & flush \\
\hline *pore position & flush & in a depression & flush \\
\hline *pore canal length & $75(10.3)$ & $65(7.1)$ & 55 (n.a.) \\
\hline becoming buried & yes & yes & yes \\
\hline *no. of cells from floor & $16-17$ & 11 & 11 \\
\hline columella & yes & inconspicuous & no \\
\hline *cells in roof filaments & 7 & $5-6$ & $4-5$ \\
\hline
\end{tabular}

\section{Lithophyllum kaiseri (Heydrich) Heydrich (1897a: 412)}

Figures 4-5; Table 2

BASIONYM: Lithothamnion kaiseri Heydrich 1897b: 64, pl. III, figs 8, 12, 13.

LeCTOTYPE: TRH, A20-1264 (Fig. 4), exclusively the small specimen in the box of the syntype of Heydrich no. 60, including thin section 6, is designated here as lectotype of Lithophyllum kaiseri (arrow on right in Fig. 4D). The larger specimen and the thin section 1150 are here excluded from the type material of Lithophyllum kaiseri. Details of the nomenclatural history are reported by Woelkerling 1993: 132; Woelkerling et al. 2005: 170.

Eтүмоlogy: the specific epithet is dedicated to the collector, Dr. A. Kaiser (Heydrich 1897b; Woelkerling 1993: 132; Woelkerling et al. 2005: 170).
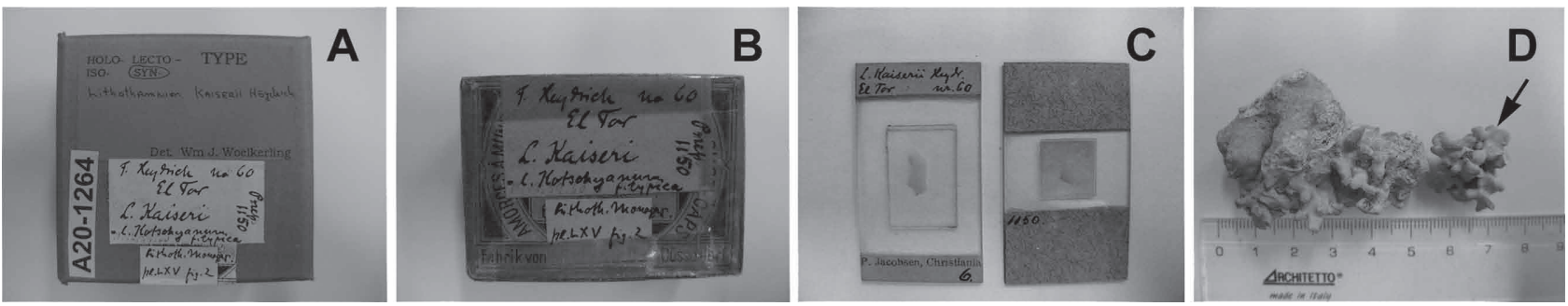

FIGURE 4. The syntype collection of Lithophyllum kaiseri Heydrich in TRH. A) Box A20-1264 in TRH. B) The carton box containing the syntype collection of L. kaiseri. C) Thin sections 6 and 1150, part of the collection A20-1264. Only slide 6 is here retained as part of the lectotype, because of the uncertain origin of slide 1150. D) The two specimens A20-1264 in TRH. The small plant (arrow) is here selected as lectotype of L. kaiseri. The larger specimen is excluded because of its uncertain origin. 
ILluStrations OF TYPe MATERial: Printz 1929: pl. 65, fig. 2.

TyPe Locality: El Tor, Sinai Peninsula (Egypt), from corals.

Material eXamined: Red Sea: Sinai Peninsula, El Tor, syntype of Lithophyllum kaiseri (Heydrich) Heydrich (leg. Kaiser: TRH, A20-1264).

GeOgRAPHIC Distribution: L. kaiseri is distributed in the Red Sea. The occurrence of L. kaiseri outside this area is unknown.
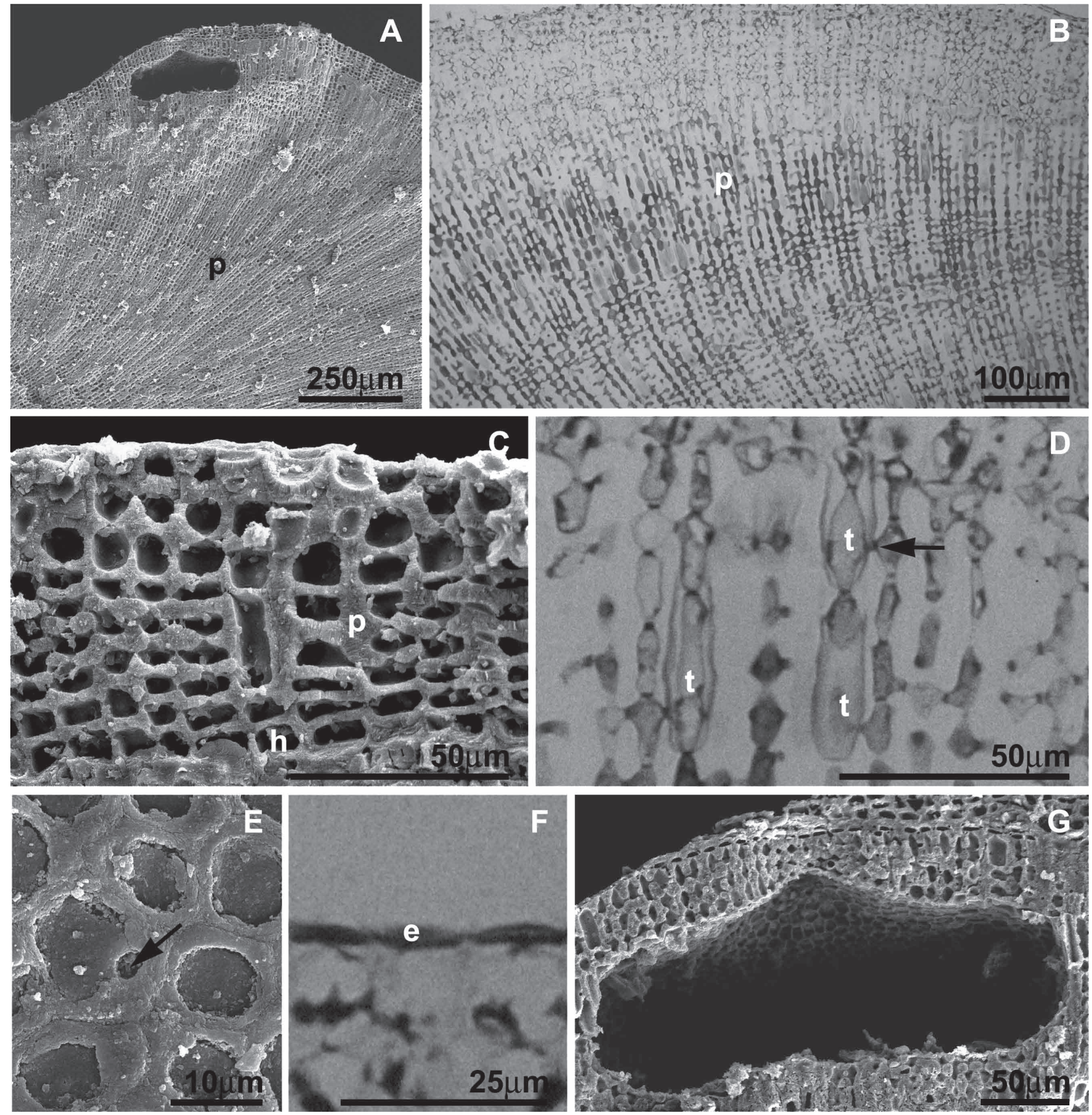

FIGURE 5. Microscopical anatomy of the small plant (Fig. 4D, arrow) lectotype A20-1264 of L. kaiseri in TRH. A) Perithallial cell filaments (p) and an empty uniporate conceptacle, SEM stub 08112012b12. Note trichocytes are not apparent. B) Perithallus (p) in slide A20-1264_8 with abundant trichocytes. C) Detail of a thin portion of the thallus with hypothallus (h) and perithallus (p) of cells connected by primary and secondary pit-connections. D) Same as in B; detail of secondary pit-connections (arrow) and trichocytes (t). E) Epithallial cells in surface view with trichocyte trace (arrow), SEM stub 08112012b12. F) Same as in B; flattened epithallial cells (e). G) Detail of an empty uniporate conceptacle chamber with 4-5 cells forming the roof filaments.

Habit And Vegetative StRucture: The lectotype of $L$. kaiseri (A20-1264, here designated as the small specimen only, in the box of the syntype of Heydrich; arrow in Fig. 4D) is apparently a broken fragment of a larger plant, nonendophytic, with fruticose growth-form (Fig. 4D on right). The protuberances have a smooth surface, are cylindrical 
or slightly compressed, branched, up to about $8 \mathrm{~mm}$ long and about $2-5 \mathrm{~mm}$ wide. The tapering protuberances are often fused together (Fig. 4D on right). Plant structure pseudoparenchymatous (Fig. 5A-B). Basal or ventral layer (=hypothallium) dimerous, hypothallial cells $7-20 \mu \mathrm{m}$ long and $10-15 \mu \mathrm{m}$ in diameter. Peripheral region $(=$ perithallium) composed of cell filaments curving outwards towards the thallus surface, L 5-30 $\mu \mathrm{m}$ long and 7-14 $\mu \mathrm{m}$ in diameter (Fig. 5B-D). Cells of adjacent filaments joined by secondary pit connections, cell fusions not observed (Fig. 5C-D). Palisade cells not observed. Single trichocytes 15-45 $\mu \mathrm{m}$ long and about 10-18 $\mu \mathrm{m}$ in diameter occurring in the perithallium and at the thallus surface (Fig. 5C-E). Single epithallial cells flattened, about 7-13 $\mu \mathrm{m}$ in diameter and 2-5 $\mu \mathrm{m}$ long (Fig. 5E-F; Tab. 2).

REPRODUCTION: Uniporate tetrasporangial conceptacles flush with the surrounding thallus surface, conceptacle chamber $270-350 \mu \mathrm{m}$ in diameter and 85-125 $\mu \mathrm{m}$ high, with a pore-canal $55 \mu \mathrm{m}$ long (Fig 5G; Tab. 2). Floor of the conceptacle chamber 11 cells below the thallus surface, including the terminal epithallial cell. Roof filaments $4-5$ cells long, including the terminal epithallial cell (Fig. 5G). Gametangial and carposporangial conceptacles unknown.

REPRESENTATIVE SEQUENCE: KP696793 (LSU).

Lithophyllum subplicatum (Foslie) comb. et stat. nov.

Figures 6-7; Table 3

BASIONYm: Lithophyllum okamurae forma subplicatum Foslie 1901a (K. Norske Vid. Selsk. Skr.: 18) (Woelkerling et al. 2005: 173).

Nomenclatural synonym: L. kaiseri? f. subplicata Foslie (1903), L. kotschyanum f. subplicatum Silva in Silva et al. (1996, p. 248) (Woelkerling et al. 2005).

LeCTOTYPE: TRH, A20-1286, includes slide 596 (Fig. 6) (Woelkerling 1993: 212).
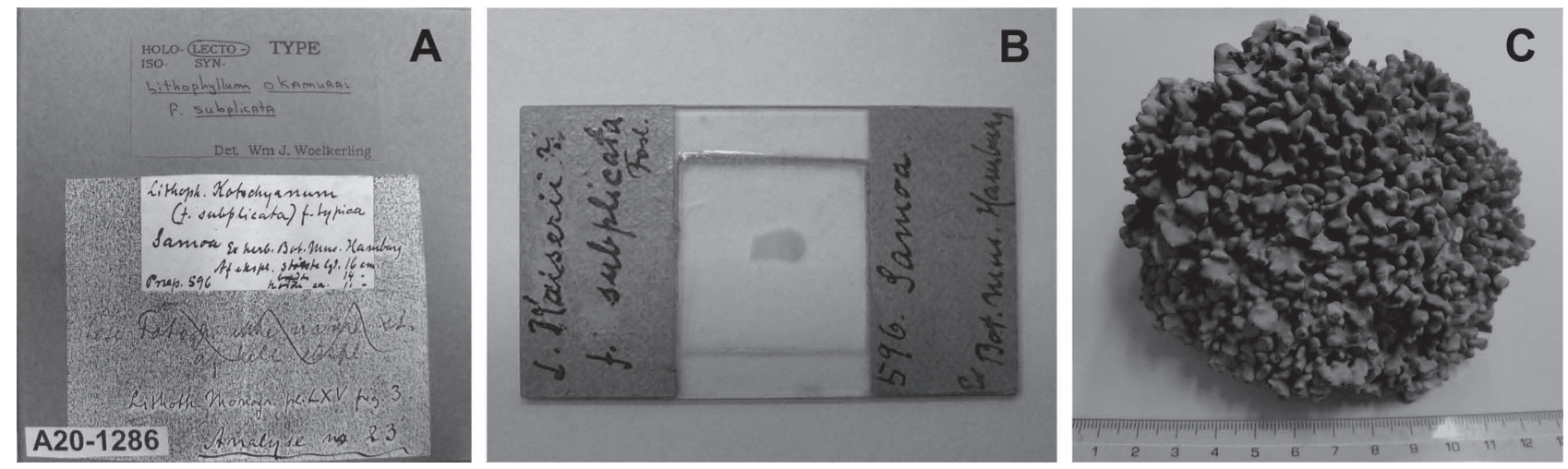

FIGURE 6. The lectotype collection of Lithophyllum subplicatum (Foslie) comb. et stat. nov. in TRH. A) Box A20-1286 in TRH. B) Thin section 596 part of the lectotype of L. subplicatum. C) The specimen A20-1286 in TRH, lectotype of L. subplicatum.

ETYMOLOGY: the specific epithet means "begged for".

Illustrations of TYPe Material: Printz 1929: pl. 65, fig. 3.

TYPe LOCALity: Samoa Islands, no collector and date given; ex Botanical Museum Hamburg (Woelkerling 1993; Woelkerling et al. 2005).

Material eXamined: Pacific Ocean, Samoa Islands, the lectotype TRH A20-1286.

HABITAT AND PHENOLOGY: unknown.

Geographic Distribution: L. subplicatum is known only from the type locality, Samoa Islands. Other entries need verification (Table 1).

Habit AND Vegetative STRUCtURE: Plants non-endophytic, with fruticose growth-form. The long protuberances are cylindrical and dichotomously branched, diverging, about 3-4 $\mathrm{mm}$ in diameter, flattened and anastomosing at their tips. The plant is $7 \mathrm{~cm}$ high and $11 \mathrm{~cm}$ in diameter (Fig. 6C).

Plant structure pseudoparenchymatous (Fig. 7A-B). Basal or ventral layer (= hypothallium) dimerous (Fig. 7B). Hypothallial cells $20-23 \mu \mathrm{m}$ long and $12-20 \mu \mathrm{m}$ in diameter (Tab. 3). Peripheral region (= perithallium) composed of filaments of cells curving outwards toward the thallus surface, $15-28 \mu \mathrm{m}$ long and 10-18 $\mu \mathrm{m}$ in diameter (Fig. 7B). Cells of adjacent filaments joined by secondary pit connections, cell fusions not observed. Palisade cells not observed. Single trichocytes $30-53 \mu \mathrm{m}$ long and about $12-15 \mu \mathrm{m}$ in diameter, abundantly distributed in the perithallium and at the thallus surface (Fig. 7C). Single epithallial cells flattened, about 10-13 $\mu \mathrm{m}$ in diameter and 2-3 $\mu \mathrm{m}$ long (Tab. 3). 

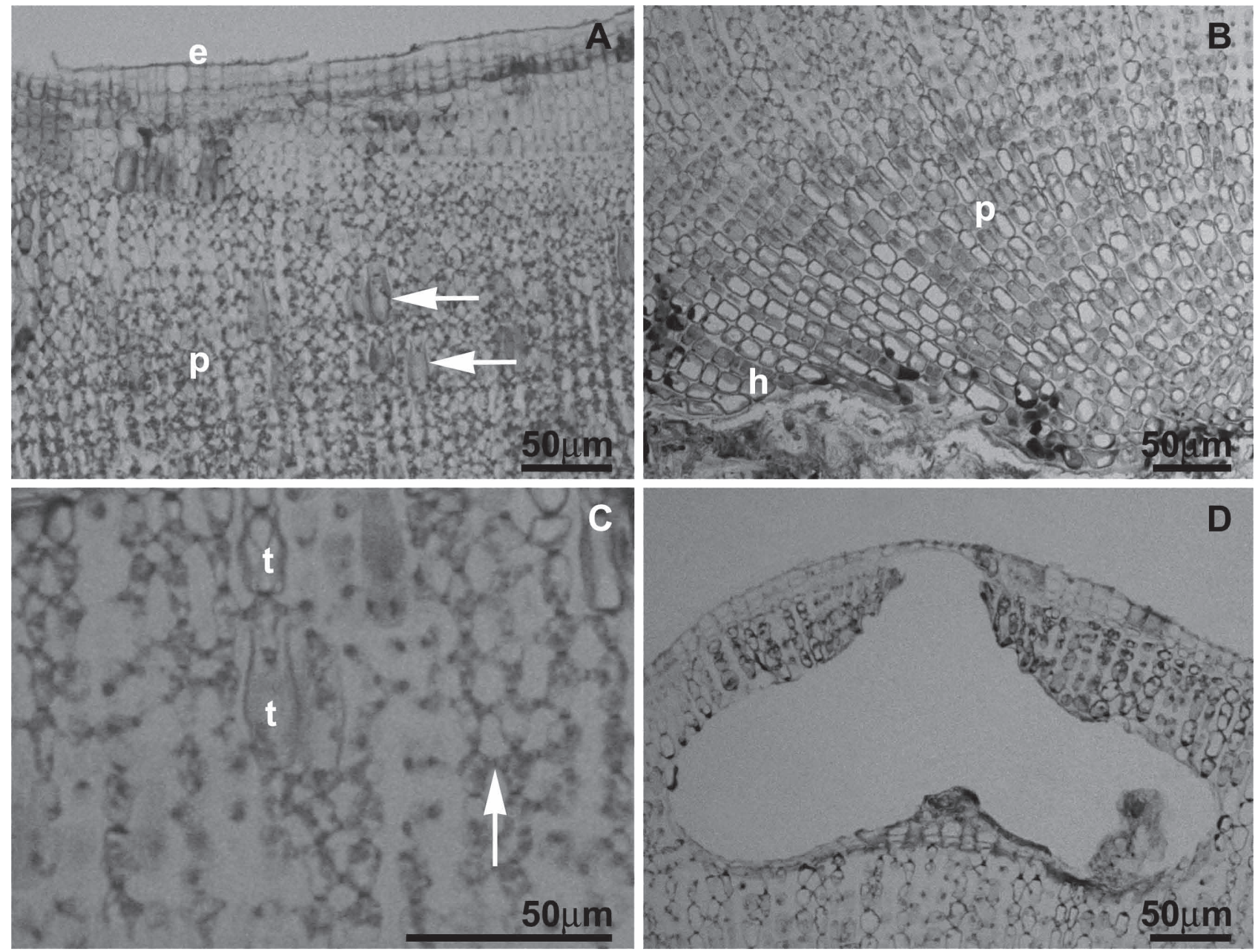

FIGURE 7. Microscopical anatomy of the lectotype of L. subplicatum (Foslie) comb. et stat. nov. TRH A20-1286 from decalcified material. A) Trichocytes (arrows) in the perithallus (p) with filaments terminating in flattened epithallial cells (e), slide A20-1286_5. B) Same as in A. Thallus dimerous, with hypothallial (ventral) cells visible on bottom left (h), each one giving rise to a filament of perithallial cells (p). C) Same as in A, with magnification of secondary pit-connections (arrow) and trichocytes (t). D) An empty uniporate conceptacle chamber with 6-8 cells in the roof filaments. Slide A20-1286_5.

REPRODUCTION: Uniporate conceptacle chambers, presumed tetra- or bisporangial, protruding over the surrounding thallus surface, becoming buried in the thallus, $330-360 \mu \mathrm{m}$ in diameter and 100-170 $\mu \mathrm{m}$ high, with pore-canal 80-110 $\mu \mathrm{m}$ long (Fig. 7D; Tab. 3). Floor of the conceptacle chamber convex upward below a central columella. The conceptacle chamber floor is $13-15$ cells below the thallus surface. Roof filaments $6-8$ cells long, including the terminal epithallial cell (Fig. 7D; Tab. 3). Gametangial and carposporangial conceptacles unknown.

REPRESENTATIVE SEQUENCE: KP696792 (LSU).

\section{Lithophyllum subreduncum Foslie 1901b: 10}

Figures 8-9; Table 3

Nomenclatural SynONym: L. kotschyanum f. subredunca Foslie.

Holotype: TRH, A20-1291, includes slide 503, ex Herb. W.G. Farlow no. XXXI (Woelkerling et al. 2005: 174); Fig. 8.

ETymology: the specific epithet means "more or less hooked".

ILlustrations OF TYPE MATERIaL: Printz 1929: pl. 65, fig. 12 (as L. kotschyanum f. subredunca).

TYPE LOCAlity: Sandwich Islands, Hawaii, collector and date unknown (Woelkerling 1993; Woelkerling et al. 2005).

Material eXamined: Pacific Ocean, Sandwich Islands, the holotype TRH A20-1291.

HABITAT AND PHENOLOGY: unknown. 

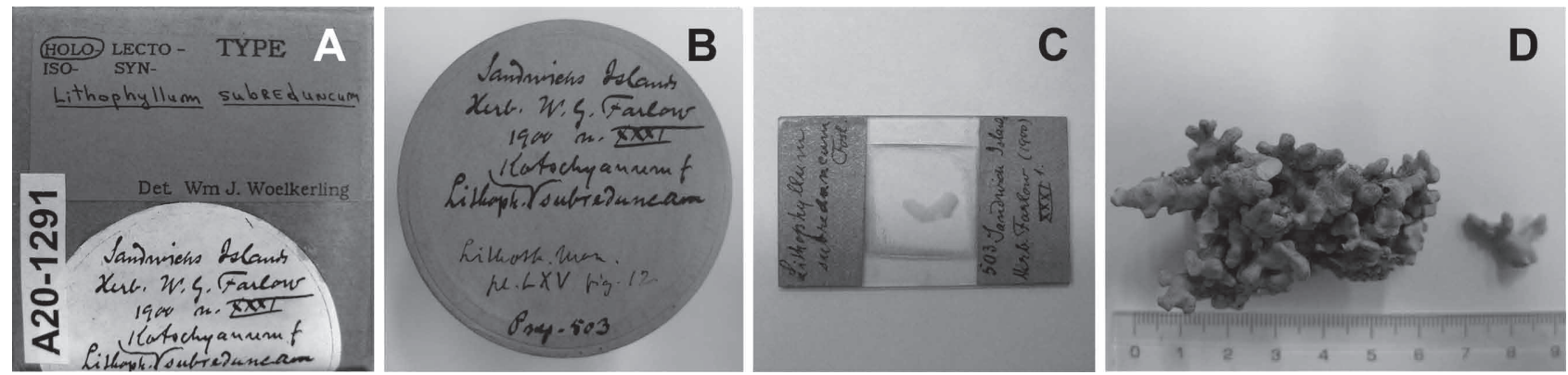

FIGURE 8. The holotype collection of Lithophyllum subreduncum Foslie in TRH. A) Box A20-1291 in TRH. B) The carton box containing the holotype of L. subreduncum. C) Thin section 503 part of the holotype of L. subplicatum. D) The specimen A20-1291 in TRH, holotype of $L$. subreduncum.

GEOGRAPHiC DistRibution: L. subreduncum is known only from the type locality, the Sandwich Islands. Other entries need verification (Table 1).
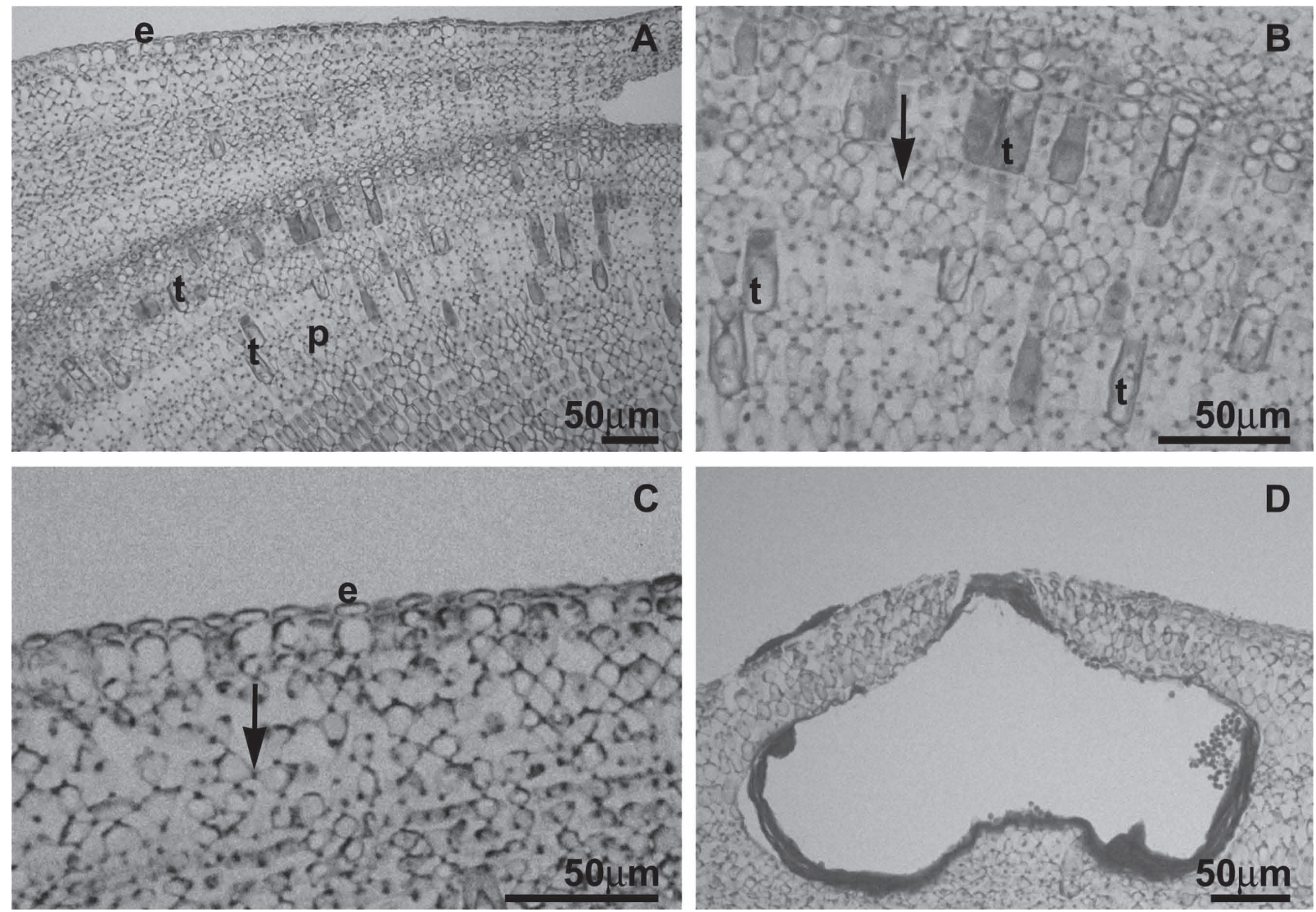

FIGURE 9. Microscopical anatomy of the holotype of L. subreduncum Foslie, slide A20-1291_2. A) Vegetative thallus with abundant trichocytes ( $\mathrm{t}$ ) in the perithallus (p), and epithallial flattened cells (e). B) Details of the secondary pit-connections (arrow) in the perithallus and the abundant trichocytes (t). C) Magnification of secondary pit-connections (arrow) and epithallial cells (e). D) A tetrasporangial conceptacle with remain of a central columella.

Habit and vegetative structure: Plants non-endophytic, with fruticose growth-form. The protuberances are cylindrical and branched, about $4 \mathrm{~mm}$ in diameter, up to $14 \mathrm{~mm}$ long, irregularly flattened and anastomosing at their tips (Fig. 8D). Plant structure pseudoparenchymatous (Fig. 9A). Basal or ventral layer (= hypothallium) dimerous. Hypothallial cells $20-23 \mu \mathrm{m}$ long and $12-15 \mu \mathrm{m}$ in diameter (Tab. 3). Peripheral region (= perithallium) composed of filaments of cells curving outwards toward the thallus surface, 20-24 $\mu \mathrm{m}$ long and 12-15 $\mu \mathrm{m}$ in diameter (Fig. 9A-C). Cells of adjacent filaments joined by secondary pit connections, cell fusions not observed. Palisade cells not observed. Single trichocytes $27-33 \mu \mathrm{m}$ long and about $12-15 \mu \mathrm{m}$ in diameter, abundantly distributed in the perithallium and at the thallus surface (Fig. 9A-B). Single epithallial cells flattened, about 10-13 $\mu \mathrm{m}$ in diameter and 2-4 $\mu \mathrm{m}$ long (Fig. 9C). 
REPRODUCTION: Uniporate conceptacle chambers, presumed tetrasporangial, weakly protruding over the surrounding thallus surface, becoming buried in the thallus, $330 \mu \mathrm{m}$ in diameter and $130 \mu \mathrm{m}$ high, with pore-canal $80 \mu \mathrm{m}$ long (Fig. 9D; Tab. 3). Floor of the conceptacle chamber convex upward below a central columella. The conceptacle chamber floor is $15-16$ cells below the thallus surface. Roof filaments 5 cells long, including the terminal epithallial cell (Fig. 9D; Tab. 3). Gametangial and carposporangial conceptacles unknown.

RePReSentative SEQUENCE: KP696788 (LSU).

\section{Lithophyllum socotraense sp. nov.}

Figure 10; Table 3

Holotype: sample DB635 (leg. Caragnano: Socotra, 15.iii.2010) including stub 09062010b6 and histological slide DB635-SO20b, conserved in TRH (TRH-A3881).

TABLE 3. Comparison of features and biometry of Lithophyllum subplicatum (Foslie) comb. et stat. nov., Lithophyllum subreduncum (Foslie) Foslie, from type material (TRH), and of Lithophyllum socotraense sp. nov., Lithophyllum yemenense sp. nov. Measurements in $\mu \mathrm{m}$, given as mean (standard deviation). $\mathrm{L}=$ length; $\mathrm{D}=$ diameter; $\mathrm{H}=$ height. Asterisk on diagnostic characters.

\begin{tabular}{|c|c|c|c|c|}
\hline & $\begin{array}{l}\text { L. subplicatum } \\
\text { lectotype }\end{array}$ & $\begin{array}{l}\text { L. subreduncum } \\
\text { holotype }\end{array}$ & L. socotraense & L. yemenense \\
\hline Distribution & Samoa Islands, Pacific & Hawaii, Pacific & Socotra Is., Arabian Sea & Red Sea, Aden Gulf, Arabian \\
\hline Life habit & $\begin{array}{c}\text { Ocean } \\
\text { non-geniculate, } \\
\text { unknown }\end{array}$ & $\begin{array}{c}\text { Ocean } \\
\text { non-geniculate, } \\
\text { unknown }\end{array}$ & $\begin{array}{l}\text { non-geniculate, as } \\
\text { rhodoliths }\end{array}$ & $\begin{array}{c}\text { Sea } \\
\text { non-geniculate, attached or as } \\
\text { rhodolith }\end{array}$ \\
\hline Growth-form & fruticose & fruticose & warty to lumpy & lumpy to fruticose \\
\hline Thallus organization & dimerous & dimerous & dimerous & dimerous \\
\hline *Hypothallial cells L x D & $21.7(1.4) \times 16.7(3.8)$ & $\begin{array}{c}20.8(1.2) \times 14.2 \\
(1.2)\end{array}$ & $15.8(0.5) \times 14.6(1.6)$ & $11.9(3.5) \times 12.5(1.8)$ \\
\hline Perithallium zonation & yes & yes & yes & yes \\
\hline Perithallial cells L x D & $24.2(4.9) \times 12.5(3.2)$ & $\begin{array}{c}21.8(1.3) \times 13.8 \\
(1.3)\end{array}$ & $16.9(3.5) \times 10.3(0.1)$ & $15.6(5.7) \times 10.2(1.6)$ \\
\hline Epithallial cells shape & flattened & flattened & flattened & flattened \\
\hline Lx D & $2.5(0) \times 10.8(1.4)$ & $2.9(0.4) \times 11(1.2)$ & $3.9(1.2) \times 10.7(2.5)$ & $2.8(0.8) \times 10.1(1.8)$ \\
\hline Trichocytes & yes & yes & yes & yes \\
\hline Asexual concept. chamber & uniporate & uniporate & uniporate & uniporate \\
\hline$* \mathrm{D} \times \mathrm{H}$ & $343.3(15.3) \times 150(35.1)$ & 330 (n.a.) x 130 (n.a.) & $213.4(24.3) \times 82.1(11)$ & $273.3(19.5) \times 103(12.5)$ \\
\hline *elevation & protruding & slightly protruding & slightly protruding & flush or weakly protruding \\
\hline *pore position & flush & flush & flush & flush \\
\hline *pore canal length & $95(15.3)$ & 80 (n.a.) & $50.8(4.5)$ & $52.1(4.3)$ \\
\hline becoming buried & yes & yes & yes & yes \\
\hline *no. of cells from floor & $13-15$ & $15-16$ & $9-11$ & $11-14$ \\
\hline columella & yes & yes & yes & yes \\
\hline *cells in roof filaments & $6-8$ & 5 & $4-5$ & $4-6$ \\
\hline Male conceptacles & unknown & unknown & unknown & \\
\hline D x H (excl. canal) & & & & $272.5(26.3) \times 41(3.5)$ \\
\hline pore canal length & & & & $46(6.5)$ \\
\hline Female concept. D & unknown & unknown & unknown & 170 \\
\hline Carposporangial concept. & unknown & unknown & unknown & \\
\hline $\mathrm{D} \times \mathrm{H}$ & & & & $325 \times 125$ \\
\hline pore canal & & & & 75 \\
\hline
\end{tabular}


Eтyмоlogy: the specific epithet refers to the type locality, the island of Socotra, Yemen.

TYPE LOCAlitY: Yemen, Indian Ocean, Ras Adho on the NE coast of Socotra Island, $22 \mathrm{~m}$ depth.

Material eXamined: Indian Ocean, NE Socotra Island: Rosh, 16 m, samples DB615-616 (leg. Caragnano: 12.iii.2010); Ras Adho, $22 \mathrm{~m}$ (the holotype) and $13 \mathrm{~m}$ (sample DB636) (leg. Caragnano: 16.iii.2010).

HaBitAT AND PHENOLOGY: plants unattached as rhodoliths, enveloping coral fragments at nucleus, at depth $>12$ m.
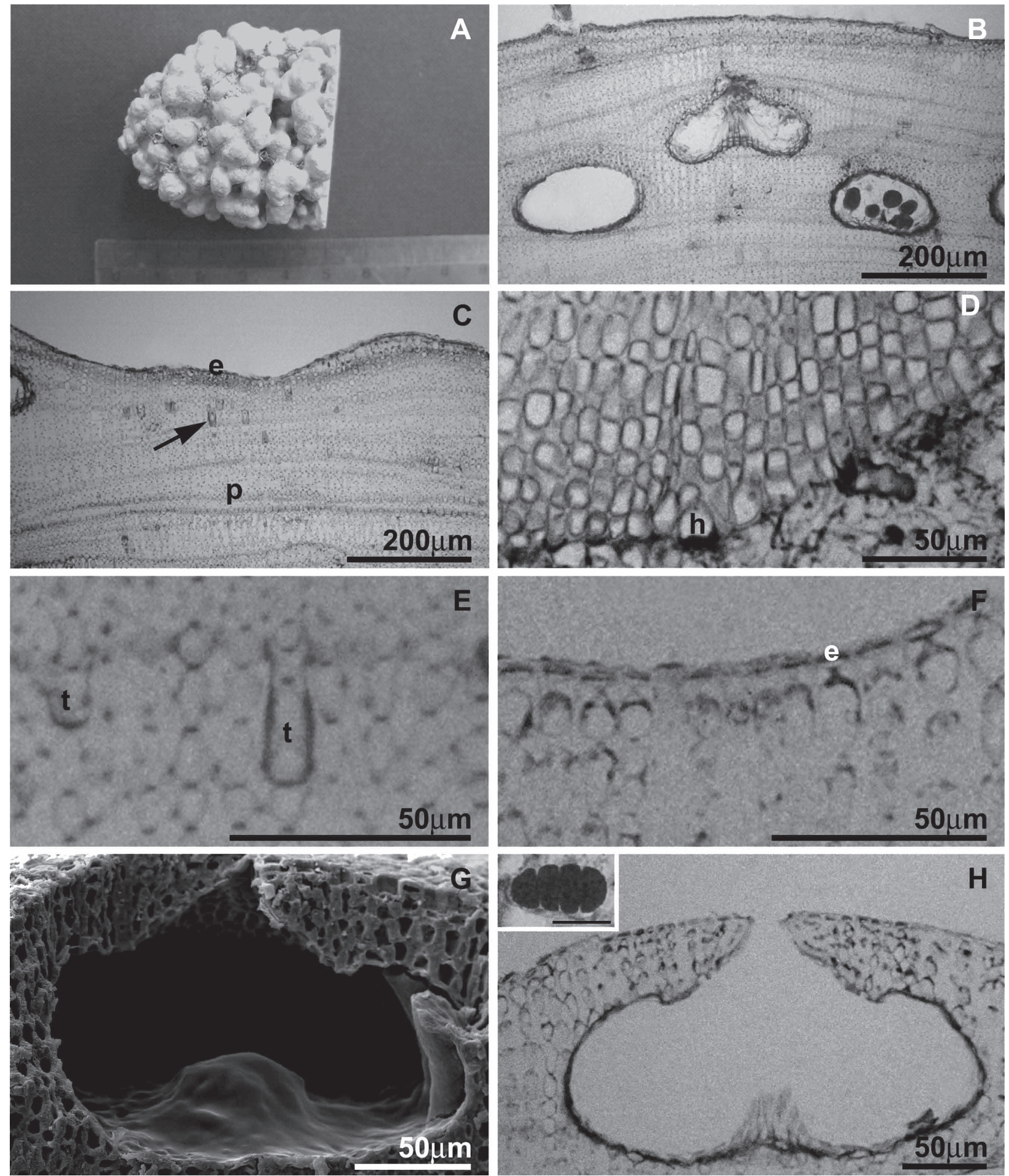

FIGURE 10. Lithophyllum socotraense sp. nov. A) The holotype, sample DB635, a rhodolith, conserved in TRH. Note the lumpy growthform. The sample has been cut for histological analyses. B) Microscopical anatomy of a fertile thallus, slide DB635-SO20b_9. C) Sparse trichocytes (arrow) in the perithallus (p) of sample DB636, slide DB636-SO25b_7; e = epithallial cells. D) Same as in C, detail of ventral hypothallial cells (h) and the dimerous organization of the thallus. E) Same as in C, magnification of trichocytes (t). F) Flattened epithallial cells (e) in slide DB635-SO20b_10. G) Tetrasporangial conceptacle with central columella in the holotype, SEM stub 09062010b6. H) Holotype sample DB635. Tetrasporangial conceptacle in slide DB635-SO20b_10; inset: a tetraspore, slide DB635-SO20b_7. 
Geographic Distribution: L. socotraense nov. sp. is known only from the NW Indian Ocean, Socotra Island.

Habit and vegetative structure: Plants non-endophytic, with warty to lumpy growth form. The protuberances have a smooth surface, up to about $5 \mathrm{~mm}$ long and about 3-6 mm wide (Fig. 10A).

Plant structure pseudoparenchymatous (Fig. 10B-C). Basal or ventral layer (=hypothallium) dimerous (Fig. 10D). Hypothallial cells $15-18 \mu \mathrm{m}$ long and 11-18 $\mu \mathrm{m}$ in diameter (Tab. 3). Peripheral region (= perithallium) composed of filaments of cells curving outwards toward the thallus surface, $12-23 \mu \mathrm{m}$ long and $10-13 \mu \mathrm{m}$ in diameter (Fig. 10CD). Cells of adjacent filaments joined by secondary pit-connections, cell fusions not observed (Fig. 10D-F). Palisade cells not observed. Single trichocytes $22-58 \mu \mathrm{m}$ long and about $12-13 \mu \mathrm{m}$ in diameter, abundantly distributed in the perithallium and at the thallus surface (Fig. 10C, E). Single epithallial cells flattened, about 7-15 $\mu \mathrm{m}$ in diameter and $2-5 \mu \mathrm{m}$ long (Fig. 10F).

REPRODUCTION: Uniporate tetrasporangial conceptacle chambers protruding over the surrounding thallus surface, becoming buried in the thallus, 180-250 $\mu \mathrm{m}$ in diameter and 60-90 $\mu \mathrm{m}$ high, with pore-canal $45-60 \mu \mathrm{m}$ long (Fig. 10G-H; Tab. 3). Floor of the conceptacle chamber convex upward below a central columella. The conceptacle chamber floor is 9-11 cells below the thallus surface. Roof filaments $4-5$ cells long, including the terminal epithallial cell (Fig. 10H; Tab. 3). Gametangial and carposporangial conceptacles not found.

RePRESENTATIVE SEQUENCES: KP696790 (LSU), KP976402 (CO1) \& KP976409 (psbA).

\section{Lithophyllum yemenense sp. nov.}

Figures 11-12; Table 3

Holotype: sample DB567 (tetrasporangial plant, Fig. 11; legit Caragnano: Balhaf, Yemen, iii.2008), including histological slides DB567-13y2, DB567-13y4, conserved in TRH (TRH-A3882).

EтYмology: the specific epithet is dedicated to the Arabian country where samples were collected.

TYPE LOCALITY: Balhaf, Yemen, on biogenic calcareous rock, $2 \mathrm{~m}$ depth.

Material examined: Red Sea: Yemen, Kamaran, 1.5 m (legit Caragnano: DB575-576, 28.ix.2009); Indian Ocean: Gulf of Aden, Yemen, Balhaf, 2-3 m (leg. Benzoni: DB559, ix 2006; DB563, xi.2006; leg. Caragnano: DB568-570, iii.2008; DB657, DB659, DB660, DB692, xi.2008); Yemen, Socotra Is., 9 m (leg. Caragnano: DB612, iii.2010).

GEOGRAPHIC Distribution: L. yemenense is distributed in the Red Sea, Gulf of Aden and Arabian Sea. The occurrence of $L$. yemenense outside this area is unknown.
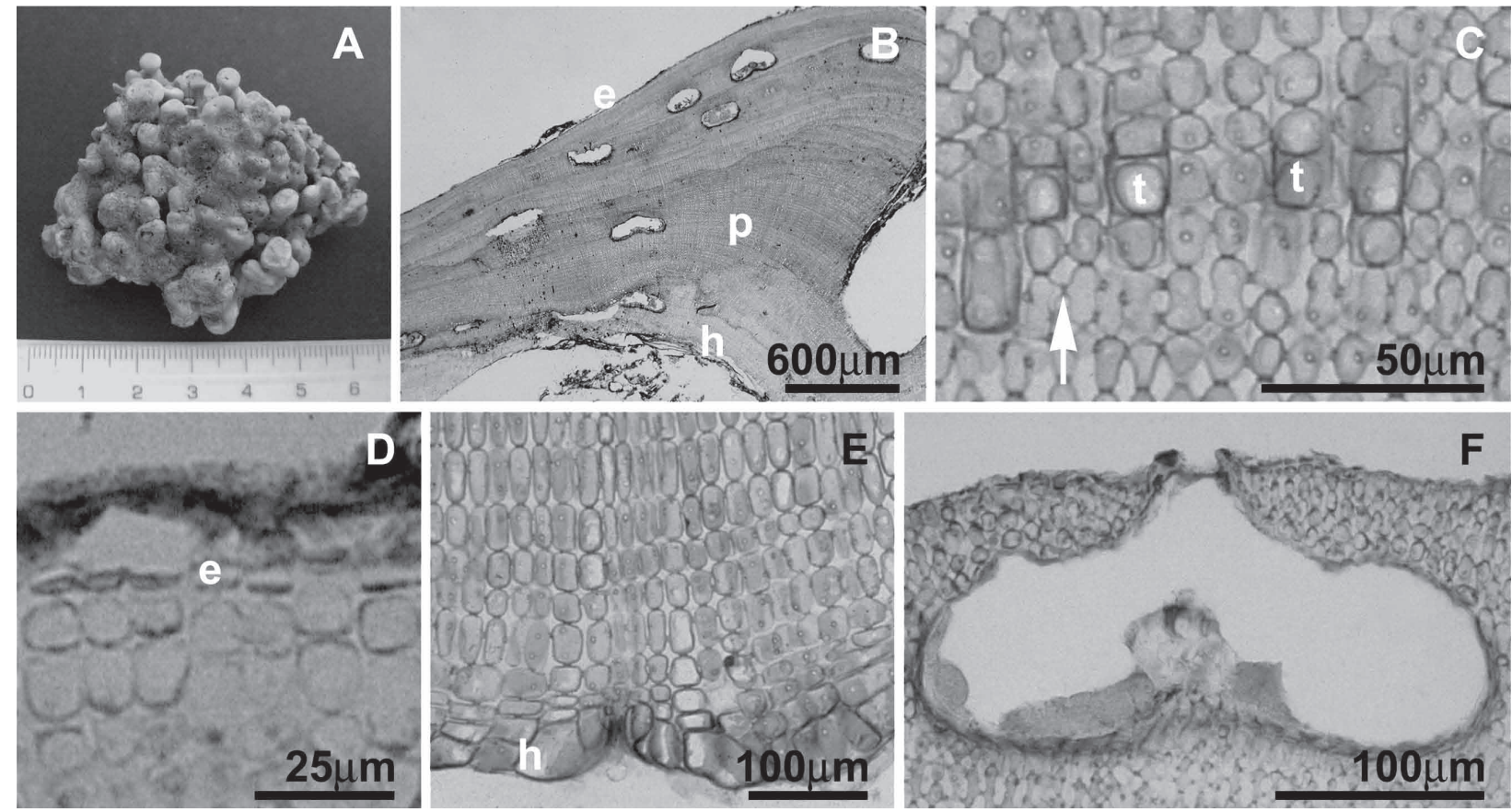

FIGURE 11. Lithophyllum yemenense sp. nov. A) The holotype, sample DB567 conserved in TRH. B) Appearance of a fertile portion of the holotype; $h=$ hypothallus; $\mathrm{p}=$ perithallus; $\mathrm{e}=$ epithallial cells, slide DB567-13y4. C) Same as in B, detail of secondary pit-connections (arrow) and trichocytes (t). D) Magnification of the flattened epithallial cells (e), slide DB567-13y2. E) Detail of B to show the dimerous organization with a ventral one-cell layer of hypothallial cells (h) each one giving rise to the perithallial filaments, slide DB567-13y5. F) Uniporate tetrasporangial conceptacle chamber with floor showing a central columella, slide DB567-13y2. 
Habit AND Vegetative StRucture: The coralline may be attached on corals or other biogenic substrate or form unattached nodules (rhodoliths). Thallus non-endophytic, encrusting, lumpy to fruticose. The protuberances, up to about $10 \mathrm{~mm}$ long and about $2-5 \mathrm{~mm}$ wide, have a smooth surface, are cylindrical or compressed, branched, sometimes fused and apically enlarged and flattened (Fig. 11A).

Plant structure pseudoparenchymatous (Fig. 11B-E). Basal or ventral layer (=hypothallium) dimerous, hypothallial cells $7-20 \mu \mathrm{m}$ long and 10-15 $\mu \mathrm{m}$ in diameter (Fig. 11E). Peripheral region (= perithallium) composed of cell filaments curving outwards towards the thallus surface, 5-30 $\mu \mathrm{m}$ long and 7-14 $\mu \mathrm{m}$ in diameter (Fig. 11B-E). Cells of adjacent filaments joined by secondary pit connections, cell fusions not observed (Fig. 11C). Palisade cells not observed. Single trichocytes 15-45 $\mu \mathrm{m}$ long and about 10-18 $\mu \mathrm{m}$ in diameter occurring in the perithallium and at the thallus surface (Fig. 11C). Single epithallial cells flattened, about 7-13 $\mu \mathrm{m}$ in diameter and 2-5 $\mu \mathrm{m}$ long (Fig. 11D; Tab. 3).

REPRODUCTION: Uniporate tetrasporangial conceptacles flush or weakly protruding above the surrounding thallus surface, conceptacle chamber $250-300 \mu \mathrm{m}$ in diameter and 80-120 $\mu \mathrm{m}$ high, with a pore-canal $50-61 \mu \mathrm{m}$ long (Fig. 11B, F; Tab. 3). Floor of the conceptacle chamber with a central columella, 11-14 cells below the thallus surface. Roof filaments 4-6 cells long, including the terminal epithallial cell (Fig. 11F).

Gametangial thalli dioecious; carpogonia and spermatangia produced in separate uniporate conceptacles (Fig. 12). Spermatangial filaments unbranched, arising from the male conceptacle chamber floor (Fig. 12A). Mature male conceptacle roof weakly raised above the surrounding thallus surface or flush, composed of 5-7 layers of cells above the chamber. Male conceptacle chambers $250-315 \mu \mathrm{m}$ in diameter and $40-45 \mu \mathrm{m}$ high, plus a pore canal $38-55 \mu \mathrm{m}$ long (Fig. 12A, Tab. 3).

Female conceptacles chamber about $170 \mu \mathrm{m}$ in diameter. Carposporangial conceptacle chamber $325 \mu \mathrm{m}$ in diameter, $125 \mu \mathrm{m}$ high, with a pore-canal about $75 \mu \mathrm{m}$ long (Fig. 12B, Tab. 3). Carposporophyte composed of a central fusion cell and short peripheral gonimoblast filaments bearing terminal carposporangia (Fig. 12B).

RePRESENTATIVE SEQUENCES: KP696789 (LSU), KP976401 (CO1) \& KP976408 (psbA).

A ML phylogenetic analysis inferred from psbA (Fig. 13) revealed that the two last species (L. socotraense and $L$. yemenense) were only distantly related to the specimens so far sequenced for this gene and available in GenBank.
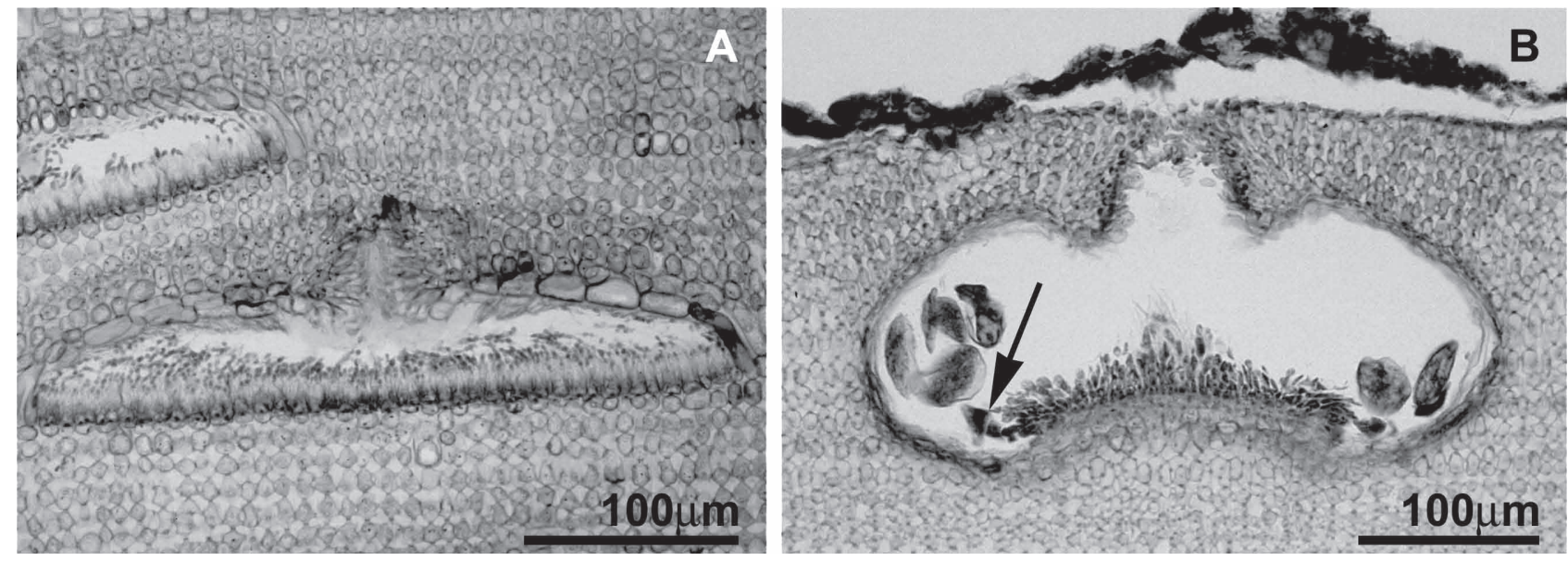

FIGURE 12. L. yemenense sp. nov., male and carposporangial plants. A) Male conceptacle with unbranched spermatangial filaments, slide DB563-4ya4. B) Carposporangial conceptacle with short peripheral gonimoblast filaments (arrow) bearing terminal carposporangia. Sample DB569, slide DB569-10y5.

\section{Discussion}

Trichocytes occur in all the Lithophyllum species dealt with in this paper (Basso et al. 2014).

After some nomenclatural changes (details in Woelkerling et al. 2005), Lithophyllum kaiseri Heydrich (Heydrich) was treated by Foslie (1909) as heterotypic synonym of L. kotschyanum (Woelkerling et al. 2005). The syntype of Lithothamnion kaiseri Heydrich (TRH, A20-1264) includes two specimens and two slides. Foslie annotated that the largest specimen was not confidently identified, probably exchanged with another box (Woelkerling et al. 2005). For this reason we selected the smallest fragment as the lectotype of Lithophyllum kaiseri. Lemoine (1965) already questioned the validity of the synonymy of $L$. kaiseri with $L$. kotschyanum, and the results of our morphological analyses support the separation of the two species. In particular, the morphological characters that can be comparatively used to identify 
L. kaiseri are: the smaller conceptacles almost flush with the surrounding thallus surface, the conceptacle floor placed 11 cells from thallus surface (16-17 in L. kotschyanum), and only 4-5 cells in roof filaments ( 7 in L. kotschyanum, Tab. 2).

In his protologue of Lithothamnion affine, Foslie (1897) described the new species with details concerning its habit: plant attached and growing on corals, surrounding the coral branches, or rhodoliths "fastened to smaller stones ...forms roundish or somewhat lobed balls on the bottom, 3-5 cm in diameter...". Later (1898) Foslie transferred Lithothamnion affine into Lithophyllum, without change in rank, and finally (Foslie 1909; Prinz 1929) reduced it to the rank of form as Lithophyllum kotschyanum f. affine (Woelkerling 1993; Woelkerling et al. 2005). He also described the two forms complanata and tuberosa on the basis of their growth form and shape of protuberances. The form complanata corresponds to the lectotype (=Lithophyllum affine f. affine, Woelkerling et al. 2005).

Our results, however, point to a separation of the two species, since L. affine Foslie (Foslie) is morphologically separated from the holotype of L. kotschyanum on the basis of its smaller tetrasporangial conceptacles with a pore opening on an apical depression of the conceptacle roof, the conceptacle floor placed 11 cells from thallus surface (16-17 in L. kotschyanum), and only 5-6 cells in roof filaments (7 in L. kotschyanum, Tab. 2; Fig. 1).

L. kotschyanum Unger, L. kaiseri (Heydrich) Heydrich and L. affine (Foslie) Foslie have similar and variable growth-form, although the integration of morphological and molecular results support their separation (Fig. 1; Tab. 2). Morphologically, the mean diameter of the tetrasporangial conceptacles, the length of the pore-canal in the tetrasporangial conceptacles (with the number of cells in roof filaments), the occurrence of a depression at the top of the conceptacle roof and the number of cells from the floor of the tetrasporangial conceptacle chamber to the thallus surface are the characters that appear collectively diagnostic for their segregation (Tab. 2 and dichotomous key). In this respect, it is worth mentioning that counting the cells at the periphery of the tetrasporangial conceptacle chamber is a very delicate operation, whose precision is easily compromised by the imperfect orientation of the thallus. Therefore we recommend to use this character with caution and, when possible, in combination with other diagnostic characters.

The lectotype of L. okamurai Foslie forma subplicata Foslie 1901a (TRH, A20-1286) has growth-form and microscopical anatomy similar to the holotype of L. kotschyanum Unger, including trichocyte occurrence and morphology (Fig. 7, Tab. 2). L. okamurai Foslie forma subplicata Foslie was transferred into L. kaiseri f. subplicata by Foslie (1903), and then into L. kotschyanum f. subplicatum by Silva in Silva et al. (1996) (Woelkerling et al. 2005).

The holotype of Lithophyllum subreduncum Foslie 1901b (TRH, A20-1291) has growth form and microscopical anatomy very similar to that of the holotype of $L$. kotschyanum Unger, including the trichocyte occurrence and morphology (Fig. 9, Tab. 2). This observation explains Foslie's conclusions, who reduced it to the rank of form after eight years from the description of Lithophyllum subreduncum as a new species, under the combination Lithophyllum kotschyanum Unger forma subreduncum Foslie (Foslie 1909; Woelkerling et al. 2005). Our analyses demonstrate that the two species differ from L. kotschyanum Unger on the basis of LSU divergence and microscopic anatomy (Fig. 1; Tabs 1-2). The comparison of the infraspecific variability of fresh collections from the type localities is a task beyond the aim of the present study. Pending further studies, we decide to follow a conservative approach by keeping the original combination for L. subreduncum Foslie 1901b, and considering L. kotschyanum f. subplicatum as a separate entity, under the new status and combination L. subplicatum (Foslie).

Lithophyllum kotschyanum Unger, L. kaiseri (Heydrich) Heydrich, L. subreduncum Foslie, L. subplicatum and L. affine (Foslie) Foslie and the new species, L. socotraense, and L. yemenense have similar and variable growthform, although the integration of results from molecular analysis and microscopical anatomy separate them as distinct species (Figs 1, 13).

The reverse primers designed in this study successfully amplified the 5'end of the LSU in herbarium specimens older than one century. The strategy to amplify short fragments to overcome the issue of degraded DNA in old specimens was appropriate and opens new perspectives to rationalize taxonomic studies of coralline algae. Amplified fragments displayed divergence up to $5.1 \%$ between $L$. affine and L. kaiseri, L. kotschyanum, L. subreduncum and L. socotraense. It is noteworthy to stress that $L$. subreduncum and $L$. socotraense have identical sequences, nonetheless, the nuclear LSU has been shown to sometimes lack of variation among closely related species (e.g. Le Gall \& Saunders 2010). Therefore, different nuclear LSU strongly supports species separation, and on the contrary, the apparent conspecificity based on this poorly variable LSU fragment appears questionable. In this case, morphology supports species separation: L. subreduncum differs from $L$. socotraense in having much larger and higher tetra-bisporangial conceptacle chamber, a longer pore canal and 15-16 cells from conceptacle floor instead of 9-11 (Tab. 2), and, moreover, the two specimens have been collected in different geographic regions. We have no data about the natural variability of $L$. subreduncum at its type locality (Hawaii), and the state of conservation of the type material does not allow to achieve further molecular 
results, nevertheless the decision to consider L. subreduncum and L. socotraense as separate species is presently the most conservative.

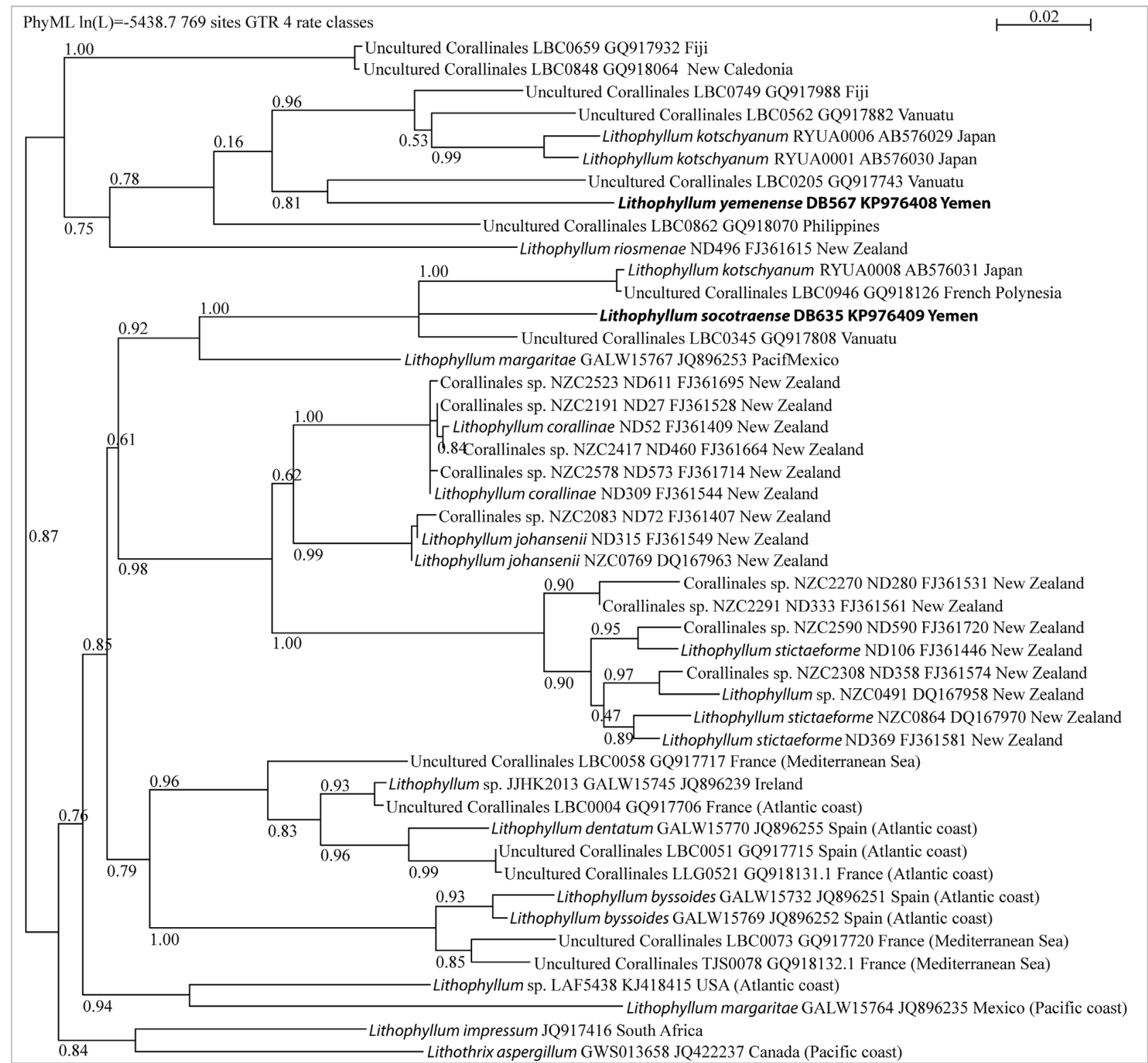

FIGURE 13. Phylogenetic analysis inferred from $p s b \mathrm{~A}$ including sequences from GenBank (with either incomplete or doubtful identification) and the type specimens of L. socotraense and L. yemenense. Supports at nodes are bootstrap values (1000 replicates).

The anatomical features of the tetrasporangial conceptacle that are here considered collectively diagnostic for species identification in Lithophyllum are: the mean diameter of the tetrasporangial conceptacles, the length of the porecanal in the tetrasporangial conceptacles (with the number of cells in roof filaments), the occurrence of a depression at the top of the conceptacle roof and the number of cells from the floor of the tetrasporangial conceptacle chamber to the thallus surface (dichotomous key).

We demonstrate here a previously unsuspected diversity within the Red Sea and NW Indian Ocean species of Lithophyllum, that increase in number from 3 (L. kotschyanum, L. orbiculatum and L. okamurae) to 7 (with the addition of $L$. affine, L. kaiseri, L. socotraense and L. yemenense). The occurrence of $L$. subplicatum and $L$. subreduncum outside their type localities in the Pacific Ocean requires further confirmation. On the basis of literature data (Silva et al. 1996; Guiry \& Guiry 2015), more than one hundred species of Lithophyllum are presently considered taxonomically accepted, although many of them, including L. orbiculatum and L. okamurae, lack a modern account or need confirmation of their geographic distribution. The complete revision of this material is beyond the aim of this work, and constitutes a challenge for future studies. 


\section{Key to species of Lithophyllum from north-western Indian Ocean ${ }^{\S}$}

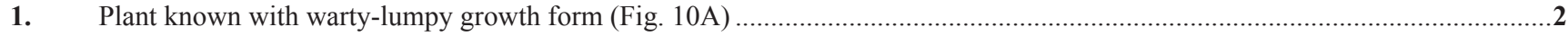

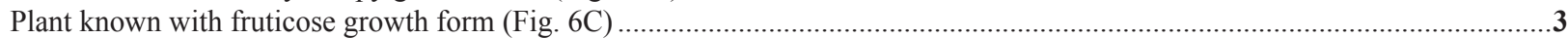

2. Mature tetra-bisporangial conceptacle slightly protruding above the thallus surface, chamber $180-250$ (mean 213$) \mu \mathrm{m}$ in diameter, and 60-90 (mean 82) $\mu \mathrm{m}$ in height, chamber floor 9-11 cell layers below the surrounding thallus surface...............L. socotraense Mature tetra-bisporangial conceptacle flush or weakly protruding above the thallus surface, chamber 250-300 (mean 273) $\mu \mathrm{m}$ in diameter, and 80-120 (mean 103) $\mu \mathrm{m}$ in height, floor 11-14 cell layers below the surrounding thallus surface ........ L. yemenense

3. Pore canal aperture in the centre of a depression (Fig. 3D), conceptacle chamber $250-280 \mu \mathrm{m}$ in diameter and $110-130 \mu \mathrm{m}$ in height, floor 11 cells below the thallus surface, and 5-6 cells in roof filaments, inconspicuous columella......................... a. affine Pore canal aperture of the tetrasporangial conceptacle chamber flush with the surface of the chamber roof (Fig. 7D, 10H), other

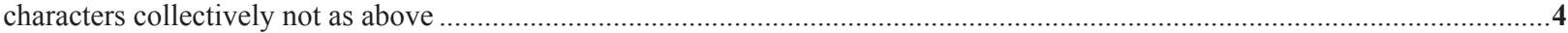

4. Mature tetra-bisporangial conceptacle with floor $>15$ cell layers below the surrounding thallus surface....................................5 Mature tetra-bisporangial conceptacle with floor $\leq 15$ cell layers below the surrounding thallus surface (Fig. 10H) ....................6

5. Mature tetra-bisporangial conceptacle with chamber 310-380 (mean 351) $\mu \mathrm{m}$ in diameter, floor $16-17$ cell layers below the thallus

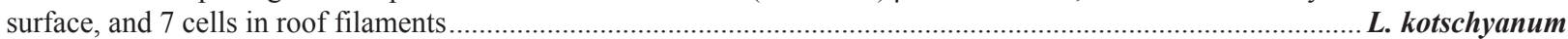
Mature tetra-bisporangial conceptacle with chamber $330 \mu \mathrm{m}$ in diameter, floor 15-16 cells below the thallus surface, and 5 cells

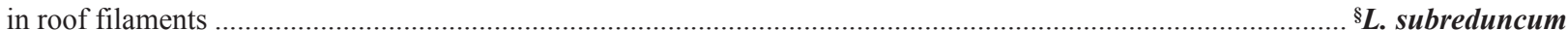

6. Mature tetra-bisporangial conceptacle with no evident columella on the chamber floor (Fig. 5G), chamber 270-350 (mean 310) $\mu \mathrm{m}$ in diameter, floor 11 cell layers below the surrounding thallus surface, $4-5$ cells in roof filaments......................... $\boldsymbol{L} . \boldsymbol{k a i s e r i}$ Mature tetra-bisporangial conceptacle with central columella on the chamber floor (Fig. 10G-H), other characters collectively not as above.

7. pore canal length $50-61 \mu \mathrm{m}$ long

L. yemenense pore canal length $>61 \mu \mathrm{m}$ long....... ........................ 8

8. Mature tetra-bisporangial conceptacle with $6-8$ cells in roof filaments ${ }^{\S}$ L. subplicatum Mature tetra-bisporangial conceptacle with 5 cells in roof filaments

L. subreduncum

${ }^{\S}$ The occurrence of L. subplicatum and L. subreduncum in the NW Indian Ocean requires further confirmation.

\section{Acknowledgments}

The authors are grateful to the Environmental Protection Authority (EPA) of Socotra for field work permit. We are indebted with Viviana Peña for her collaboration in the molecular work. We acknowledge Fouad Naseeb (EPA Socotra) for logistic assistance. We also thank Robert Hirst and Yemen LNG, Claude Chaineu and Total E\&P, for allowing fieldwork and sampling, and Eric Dutrieux and Créocean for logistic and organization support. We wish to thank S. Basheen (Professional Divers, Yemen) for his help in field work and Francesca Benzoni for exciting scientific discussions and sampling contribution. We are grateful to Tommy Prestø and Kristian Hassel, Herbarium TRH, for providing specimens from the collections in Trondheim, Norway. SEM pictures were provided by Paolo Gentile, SEM-EDS laboratory of Milano-Bicocca University. The molecular data were produced at the Service de Systématique Moléculaire of the Muséum National d'Histoire Naturelle (CNRS - UMS 2700) with funds provided by the ATM 'Taxonomie moléculaire: DNA Barcode et gestion durable des collections'. AC was funded by the $\mathrm{PhD}$ programme of the Milan-Bicocca University.

\section{References}

Adey, W.H. \& Adey, P.J. (1973) Studies on the biosystematics and ecology of the epilithic crustose Corallinaceae of the British Isles. British Phycological Journal 8: 343-407. http://dx.doi.org/10.1080/00071617300650381

Bailey, J.C. (1999) Phylogenetic positions of Lithophyllum incrustans and Titanoderma pustulatum (Corallinaceae, Rhodophyta) based on 18S rRNA gene sequence analyses, with a revised classification of the Lithophylloideae. Phycologia 38: 208-216. http://dx.doi.org/10.2216/i0031-8884-38-3-208.1

Basso, D., Caragnano, A. \& Rodondi, G. (2014) Trichocytes in Lithophyllum kotschyanum and Lithophyllum spp. (Corallinales, Rhodophyta) from the NW Indian Ocean. Journal of Phycology 50: 711-717.

http://dx.doi.org/10.1111/jpy.12197

Basso, D. \& Rodondi, G. (2006) A Mediterranean population of Spongites fruticulosus (Rhodophyta, Corallinales), the type species of Spongites, and the taxonomic status of S. stalactitica and S. racemosa. Phycologia 45: 403-416. http://dx.doi.org/10.2216/04-93.1

Basso, D., Rodondi, G. \& Mari, M. (2004) A comparative study between Lithothamnion minervae and the type material of Millepora fasciculata (Corallinales, Rhodophyta). Phycologia 43: 215-223. 
http://dx.doi.org/10.2216/i0031-8884-43-2-215.1

Bressan, G. (1974) Rodoficee calcaree dei mari italiani. Bollettino della Societa Adriatica di Scienze, 59: 1-132.

Chamberlain, Y.M. \& Irvine, L.M. (1994) Lithophylloideae Setchell. In: Irvine, L.M. \& Chamberlain, Y.M. (Eds.) Seaweeds of the British Isles. Vol. 1 Rhodophyta, Part 2B, Corallinales, Hildenbrandiales. HMSO, London, pp. 58-112.

Chamberlain, Y.M. (1996) Lithophylloid Corallinaceae (Rhodophyta) of the genera Lithophyllum and Titanoderma from southern Africa. Phycologia 35: 204-221.

http://dx.doi.org/10.2216/i0031-8884-35-3-204.1

Foslie, M. (1897) On some Lithothamnia. Det Kongelige Norske Videnskabers Selskabs Skrifter 1: 1-20.

Foslie, M. (1898) List of species of the Lithothamnia. Det Kongelige Norske Videnskabers Selskabs Skrifter 3: 1-11.

Foslie, M. (1901a) Den botaniske samling. Det Kongelige Norske Videnskabers Selskabs Aarsberetning 9: 18.

Foslie, M. (1901b) New Melobesiae. Det Kongelige Norske Videnskabers Selskabs Skrifter 1900 (6): 1-24.

Foslie, M. (1903) The Lithothamnia of the Maldives and Laccadives. In: Gardiner, J.S. (Ed.) The fauna and geography of the Maldive and Laccadive Archipelagoes. 1. Cambridge University Press, Cambridge, England, pp. 460-471.

Foslie, M. (1909) Algologiske notiser. VI. Det Kongelige Norske Videnskabers Selskabs Skrifter 1909 (2): 1-63.

Guiry, M.D. \& Guiry, G.M. (2015) AlgaeBase. World-wide electronic publication, National University of Ireland, Galway. Available from: http://www.algaebase.org (accessed 7 December 2014)

Harper, J.T. \& Saunders, G.W. (2001) Molecular systematics of the Florideophyceae (Rhodophyta) using nuclear large and small subunit rDNA sequence data. Journal of Phycology 37 (6): 1073-1082.

http://dx.doi.org/10.1046/j.1529-8817.2001.00160.x

Heydrich, F. (1897a) Melobesiae. Berichte der Deutschen Botanischen Gesellshaft 15: 403-420.

Heydrich, F. (1897b) Corallinaceae, insbesondere Melobesieae. Berichte der Deutschen Botanischen Gesellshaft 15: 34-70.

Heydrich, F. (1902) Quelques nouvelles Mélobésiées du Muséum d'Histoire naturelle de Paris. Bulletin du Muséum D'Histoire Naturelle 8: 473-476.

Holmgren, P. K., Holmgren, N. H. \& Barnett, L. C. (Eds.) (1990) Index Herbariorum Part I: The Herbaria of the World. 8 Ed.. New York Botanical Garden, New York, U.S.A, 633 pp.

Le Gall, L. \& Saunders, G.W. (2010) DNA barcoding is a powerful tool to uncover algal diversity: a case study of the Phyllophoraceae (Gigartinales, Rhodophyta) in the Canadian flora. Journal of Phycology 46: 374-389.

http://dx.doi.org/10.1111/j.1529-8817.2010.00807.x

Lemoine, M. (1965) Algues calcaires (Mélobésiées) recueillies par le Professeur Drach (croisière de la Calypso en Mer Rouge, 1952). Bull. Inst. Océanogr. Monaco 64: 1-20.

Maneveldt, G.W., Chamberlain, Y.M. \& Keats, D.W. (2008) A catalogue with keys to the non-geniculate coralline algae (Corallinales, Rhodophyta) of South Africa. South African Journal of Botany 74: 555-566. http://dx.doi.org/10.1016/j.sajb.2008.02.002

Printz, H. (1929) M. Foslie - Contribution to a monograph of the Lithothamnia. Det Kongelige Norske Videnskabers Selskabs Museet, Trondheim, $60 \mathrm{pp}, 75$ pls.

Schneider, C.W. \& Wynne, M.J. (2007) A synoptic review of the classification of red algal genera a half a century after Kylin's "Die Gattungen der Rhodophyceen". Botanica Marina 50: 197-249. http://dx.doi.org/10.1515/BOT.2007.025

Silva, P.C., Basson, P.W. \& Moe, R.L. (1996) Catalogue of the Benthic Marine Algae of the Indian Ocean. University of California publications in Botany 79, University of California Press.

Unger, F. (1858) Beiträge zur näheren Kenntniss des Leithakalkes, namentlich der vegetabilischen Einschlüsse und der Bildungsgeschichte desselben. Denkschriften der Kaiserlichen Akademie der Wissenschaften, Mathematisch-Naturwissenschaftliche Classe 14: 13-35.

Woelkerling, W.J. (1988) The Coralline Red Algae: An Analysis of the Genera and Subfamilies of Nongeniculate Corallinaceae. British Museum (Natural History) Oxford University Press, London, 268 pp.

Woelkerling, W.J. (1993) Type collections of Corallinales (Rhodophyta) in the Foslie Herbarium (TRH). Gunneria 67:1-289.

Woelkerling, W.J. \& Campbell, S.J. (1992) An account of southern Australian species of Lithophyllum (Corallinaceae, Rhodophyta). Br. Mus. nat. Hist. (Bot) 22: 1-107.

Woelkerling, W.J., Gustavsen, G., Myklebost, H.E., Prestø, T. \& Såstad, S. (2005) The coralline red algal herbarium of Mikael Foslie: revised catalogue with analyses. Gunneria 77: 1-625.

Woelkerling, W.J., Irvine, L.M. \& Harvey, A.S. (1993) Growth-forms in non-geniculate coralline red algae (Corallinales, Rhodophyta). Australian Systematic Botany 6: 277-293.

http://dx.doi.org/10.1071/SB9930277

Womersley, H.B.S. (1996) The marine benthic flora of southern Australia. Rhodophyta - Part IIIB Gracilariales, Rhodymeniales, Corallinales and Bonnemaisoniales. Australian Biological Resources Study, Canberra, Australia. 